\title{
Abandoned Places and Urban Marginalized Sites in Lugoj Municipality, Three Decades after Romania's State-Socialist Collapse
}

\author{
Ioan Sebastian Jucu *(1) and Sorina Voiculescu \\ Department of Geography, Faculty of Chemistry, Biology, Geography, West University of Timișoara, \\ 300223 Timișoara, Romania; sorina.voiculescu@e-uvt.ro \\ * Correspondence: ioan.jucu@e-uvt.ro
}

Received: 10 August 2020; Accepted: 4 September 2020; Published: 16 September 2020

\begin{abstract}
The postsocialist process of urban restructuring came with important spatial, social, and economic consequences. This triggered important transformations that remain palpable in the everyday texture of urban life, spatial patterns, and even the internal structures of the city. Every urban settlement was bound to contribute to the state socialist industry so that postsocialist urban transformations also included multiple aspects of dereliction and ruination of the socialist industrial assets. Threatening postsocialist urban formations and sustainability, the most common feature is collective neglect at national, regional, and local scales. The transition from state-socialist forms of production to the current market-based system poses many difficulties. This article specifically investigates the problems of urban industrial ruins in Lugoj-which are typical for medium-sized postsocialist municipalities in Romania. The research draws on qualitative data gathered by the authors through semi-structured interviews, personal communication, and oral histories and continuous infield observation (2012-2019). The findings unveil the production and the reproduction of abandoned spaces in Romanian urban settlements in the absence of specific regeneration programs and policies on urban redevelopment and marginalized areas. The analysis reveals that urban ruins harm the quality of life in local communities, damaging both the urban landscape and local sustainability. Further actions for local urban regeneration are urgently needed.
\end{abstract}

Keywords: urban ruins; industrial ruins; local dereliction; postsocialism; Lugoj

\section{Introduction}

In the recent context of postsocialist geographies of de-/reindustrialization, ruin creation, and place making, the present study deals with de-/reindustrialization, urban dereliction, and ruins, a family of topics, both fascinating and omnipresent in cities throughout the world [1-3]. The article examines the spatial results of local economic changes with urban ruined sites left in the wake of the transition from the state-socialism to a market economy. Furthermore, the paper draws on the local variables situated in the cities and to the "specific political, economic, social and cultural relations" [4] (p. 43), associated to particular policies required at the local level [5]. The analysis focuses on the municipality of Lugoj in Romania, a postsocialist country, which fills the gap in the present knowledge of the material and institutional dynamics of ruin creation in Eastern European societies [2,6,7]. The purpose of this contribution is to discuss the postsocialist urban ruins in Lugoj, and to explain their presence, 30 years after the collapse of state-socialism. Against the general background of processes creating Romanian urban ruins, this paper investigates the urban dereliction and production of urban ruins as exemplified by a medium-sized city that is categorized as a nonmetropolitan town. This topic is not limited to a singular type of ruin, but can take a myriad of forms. Outlining a variety of ruins in the cities, 
the empirical data explains the local government's indifference to the postsocialist ruins production, their consequences in the urban landscapes, and the local impact on the local restructuring [4]. The study emphasizes the postsocialist economic transformations through which urban ruins intensely mushroomed [8-16]. Despite a rich body of literature dealing with the postsocialist urban identity formation as well as the social and economic consequences of the cities' restructuring [17-31], the issues of urban dereliction remain peripheral at the local level. Against such a background, "scholarly interest in ruins and derelict spaces has intensified over the last decade", the recent studies being disparate, with no sustained investigation. Furthermore, "research into ruins can inform and energize critical investigations of how expressions of power and resistance, relegation and recuperation, circulate and inhere in all spaces" [6] (pp. 465, 480). Simultaneously, unused urban places are important in the contemporary urbanization models [26] claiming attention in the present scholarly debates under the new capitalist rules and more involvement of local governments in the local urban development in the postsocialist economic contexts [27].

Ruins are products of postsocialist economic transformations that, fundamentally, dramatically, and unevenly, changed the postsocialist communities [28-42]. In the process of postsocialist urban regeneration, the cities from Central and Eastern European Countries went through different stages in their readjustment to the new market-oriented economies. As a result of the postsocialist economic restructuring, some decayed urban places of these cities were partly or completely (re)developed under renewal policies, while other urban sites and industrial districts remained derelict, thus, portraying different stages of urban regeneration $[43,44]$. Derelict areas expose the local authorities' neglect or the absence of restoration strategies and policies on the local political agendas in urban postsocialist planning, and the tensions between centralized management and local decentralization, with the state being a "product of antagonisms" [45] (p. 84), and a "sum of multiple divergent projects, rather than a coherent actor" [46] (p. 281). However, urban ruins in the Romanian cities appear as places of indifference during the transition from the centrally planned economy to a post-90 economic capitalism, empowered by globalization, neoliberal rules, and private capitals [21,47-50]. The material existence of the urban ruins shows the difficulties of economic transition, the spatial inequalities of capitalism [51], controversial actions, and real estate speculation [52]. Furthermore, as Beesley [53] argued, corruption as a feature of the present globalization with multiple and deeply rooted causes in post-90 economic development, generated significant consequences in the local urban regeneration process. The absence of vision in the national policies, with wrong interventions and mismanagement in the postsocialist urban planning regulations, are important contributors in generating urban dereliction in the Romanian postsocialist towns.

Considering postsocialist formation of the urban landscapes on specific cities and towns, and their neoliberal landscapes of deception [50,54], this paper confirms the recent knowledge, focusing on the Romanian urban dereliction, through a particular local case study on a former state-socialist, nonmetropolitan industrial town: The municipality of Lugoj. The core argument of this sample evolves from the little attention paid to the Romanian small and medium-sized municipalities, with $52.55 \%$ of the urban population living in nonmetropolitan areas [55]. The analysis brings to the fore the fact that Lugoj is a third-tier city with de-/reindustrialization and ruin production, generating particular landscapes [56]. This is because nonmetropolitan areas and medium-sized municipalities very often benefited from small interventions, small attention from governments, and little interest for researchers, but generated big opportunities for controversial actions. This could lead to a particular understanding of the understudied or misunderstood piece of knowledge on the topic, with the opportunity to develop new local policies in urban regeneration. 
Lugoj was selected for this case study because of its old industrial traditions. Products made in Lugoj's emblematic factories and workshops were sold in Romania and across Europe. Now, three decades after the breakdown of state-socialism, many of these former factories remain in ruins with no further opportunities to be repurposed or redeveloped. Following trends across Europe for capitalist development in the late 19th and early 20th centuries, Lugoj's industry included important manufactures, which provided goods throughout the Austro-Hungarian Empire and acted as a magnet for migration through ample job opportunities. During the state-socialist period, capitalist factories were re-industrialized and nationalized, resulting in a massive surge in industrialization. Lugoj was an emblematic town in the light industry sector, especially well known for its textiles that concentrated female workers. With the socialist heavy industry, this largely female local labor force would be balanced with male laborers brought in to work for the new industrial plants. Postsocialist de-industrialization completely altered the industrial heritage of the town with changing trajectories of its economic and urban geographies. In this process, all of Lugoj's flagship factories failed. As their production ended they began their decay into marginalized and abandoned places. Three decades after state-socialism's collapse, these ruins still remain in the local urban landscape as blights in need of attention for regeneration. Although metropolitan and other larger cities tended to have a faster pace of regeneration for their declined places, second-tier and third-tier towns lag behind in their local renewal $[56,57]$.

This study provides critical insight into the shifting landscapes of postsocialist local economic changes tracing the transformation in the local urban patterns associated with the post- 90 restructuring and urban ruins, because ruins cannot be left alone to "simply exist in their mute materiality" [58] (p. 692). Furthermore, it is important to understand the manner in which people live with ruins [59], the ways which local governments manage or cope with urban dereliction and how the ruins alter the urban functionality and broader landscapes. Our research raises the issues of recapitalizing these ruins as parts of postsocialist dereliction. Since ruins are often symbolic sites, with important meanings, relating the past with the present urban policies, they are important for our understanding of the circumstances of their abandonment, demolishment, and regeneration, through national and local policies [52] and their "potential directions for future forms of sociality" [13] (p. 1102).

While "transformation of unused urban space follows a global trend" of urban governance [26] (p. 49), experiences of advanced societies, remain less applied in Romania, with ruins standing neglected by the local development agendas. Why and how did the ruins appear in the Romanian cities? What types of ruins appeared? What claim does the voice of the local community have towards ruins and urban dereliction? To what extent do urban ruins alter the inner patterns of the cities and towns? All these are the questions on which this study focuses. To analyze the topics of Romanian urban dereliction, the study proceeds in a few sections. The first concerns the theoretical background of urban ruins, setting the scene for the empirical research, while the second presents research methodology. In the third section, the article focuses on the urban dereliction, including a general overview on the Romanian cities, and the specific sampled case study; the section then explains the rising, the presence, and the consequences of ruined places in the local community. The final part frames the conclusions, outlooks, and some tailor-made recommendations, reflective and applicable for all Romanian nonmetropolitan areas, since urban dereliction appeared as a common feature in the most Romanian urban settlements.

\section{Setting Theoretical Background on Urban Dereliction and Ruins}

The issue of urban ruins and derelict places is topical and complex within the recent uneven geographies of postsocialism [6-9,60-62]. Oftentimes, studies approach ruins to understand their formation, their sense and their (un)identity in the cities. As "debris of global capitalism" [12] (p. 1037), ruins illustrate the nothingness of order [63] being residual and unproductive sites. Considering ruins as "symbols of failure and abandonment" showing "municipal indifference and social stagnation" $[6,8]$ (p. 475, p. 165), they unveil the mirage of the current capitalism, and neoliberalism as a way of progress, thus, influencing the urban political programs $[47,64]$. Between creative 
and brutal destruction [65,66], ruins are collapsed spaces "in a pool of dust, regrets and corruption" $[18,20,67]$ (p. 241), with the latter fuelled by the present globalization [53]. Against such a background, the ruins provide tangible experiences of the past in the current material world and the future [68,69]. Ruins are dead, awkward, loose, and derelict spaces [70,71], where nothing happens. Conceptualized as null places, drosscapes, or urban interstices [72-74], urban derelict areas are previously developed industrial or nonindustrial sites that are now vacant, abandoned, or under-used, with opportunities for their further redevelopment $[26,75,76]$. In line with ruins production, urban dereliction appears as "process" and "object" [77] (p. 6). The process of dereliction, which is fuelled by political and economic changes [26], by the state-socialist industry decline, and by dismantled state-socialist ideologies related to the economic development of the states $[16,20,78]$. As objects, ruins are part of the ignorance of the local postsocialist governments, unveiling local mismanagement in urban regeneration.

Consequently, derelict places appeared as ruined and abandoned factories. Related industrial or nonindustrial facilities appeared also as ruined sites in the cities [2,76,79-81]. Urban dereliction is obvious in vacant military sites, in urban wastelands places, in blank areas, in ruined rail places, and in collapsed buildings in residential districts [79,82-85]. All these are connected to the historical, social-economic, and political contexts that appeared in Romania, under the postsocialist umbrella of transition from the state-socialist policies to a global market economy and neoliberal policies $[49,86,87]$. Dereliction reveals negative relations and tensions between de-/reindustrialization and the post-90 market reforms [48], and between centralized state power and local government decentralization. These tensions in urban governance are responsible for the production of the local urban dereliction of the medium-sized towns. They had to face multiple changes, consequences, and opportunities. While some towns that relied on a particular heavy industry encountered massive declines, shrank, and even collapsed after they closed, some small-sized towns with complementary industrial branches closely related to old manufacturing traditions had the chance to survive urban dereliction and spark local processes of de-/reindustrialization.

\section{Data, Materials, and Methods}

To explain the Romanian urban dereliction, multiple data sources and methods were used all through this study. A mixed-method approach and a combination of data gathering, based on the history of the sites and interviews with local residents, city planners, and stakeholders to propose solutions to the city's problems, were helpful in investigating the local urban dereliction. The starting point of the research as Mah [1] suggests was an infield, participatory, and ethnographic observation of ruins in different Romanian cities and in a sampled site investigated in-depth. Empirical sources include: (1) Primary literature review, media analysis-press and documentaries, from national to local [88] and old monographs of the former productive state-socialist factories; (2) The authors' direct experience [89] of ruins, and infield and participatory observation, with investigated sites repeatedly visited, between 2012 and 2019, were useful in gaining important accounts on ruins' reproduction under post-90 economic changes at the local level; (3) Since statistical data on ruins are unavailable, an ethnographic approach to ruins were used, together with first-person accounts of places analysis [12]; (4) Qualitative research was conducted based on interviews, personal conversations and talks with local key actors in the local government, residents and ex-workers in ruined factories (fifteen in each study area); (5) An in-depth analysis of a case study with specific investigated sites was considered; (6) To assess the local urban dereliction, an inventory of the ruined sites was made, categorizing the various urban derelict places; (7) Empirical data provided meaningful insights in understanding the postsocialist reproduction of ruins and the local ways of life of residents in/with those derelict places. 
To investigate the general background of the processes that led to Romania's urban ruins, media analysis was used including newspapers, magazines, and three documentaries from Romanian national television. Understanding the production of ruins was informed by participant observation in large cities (Timişoara, Braşov, Craiova, and Bucharest) and medium- and small-sized towns (Făgăraş, Buziaş, Făget, Ilia, Azuga etc.). The study builds on previous research on postsocialist derelict spaces conducted by the co-authors in addition to a thorough literature review.

Against this general context, the municipality of Lugoj was selected as a case study to find out the specificities of its urban dereliction, but also the similarities with other small- and medium-sized municipalities. Regarding the selected case-study, the municipality of Lugoj (a nonmetropolitan area) was sampled, because one of the authors live in this town, witnessing the local urban degradation and the emergence of different derelict places and wondering how long these ruins will continue to exist in their 'mute materiality' [58] (p. 692). These former productive state-socialist sites are ghosts of a community's heritage [9], confirming that 30 years after the state-socialism collapse, they are still present and, as Schönle [58] observed, it is important to know how long from now on these ruins will be ignored, with local authorities doing nothing. To understand the issues of local ruins and urban regeneration programs, an in-depth interview was conducted with the director of Urban Planning Directorate from the City Hall of Lugoj. Then, three interviews were conducted with three former directors/managers of the local flagship factories to understand the local decline of the industrial plants from the inside. These interviews represent valuable proof on the entire process of dereliction from the standpoint of the actors involved in the process before and after the decline of the facilities. In addition, discussions, personal conversations, and oral histories of local residents were useful to capture the local residents' perception of these ruined and abandoned sites. In this regard, two lines of questioning were followed. On one hand, we were interested in how the former workers living in the neighborhoods of the ruined sites perceived ruins and if they affectively identity themselves with these abandoned places. On the other hand, we extended our inquiry to the pragmatic position of the residents as persons who only live in the proximity of ruined sites without any emotional attachment. To determine this, we addressed the question related to life quality in these areas. The types of data collected in relation to the particular investigated places are detailed in Table 1.

Table 1. Details on the qualitative methods used in the sampled case study analysis.

\begin{tabular}{|c|c|c|c|c|}
\hline Method & Interviews & $\begin{array}{c}\text { No. of } \\
\text { Interviews and } \\
\text { Personal } \\
\text { Conversations }\end{array}$ & Area & Observations \\
\hline \multirow{3}{*}{ Interviews } & 4 interviews & 4 & \multirow{3}{*}{ Not applicable } & \multirow{3}{*}{$\begin{array}{l}\text { Semi-structured interviews with } \\
15 \text { questions, duration of } 60 \text { min each. } \\
\text { The questions revolved around on the } \\
\text { production of derelict places and their } \\
\text { further possibilities of regeneration. }\end{array}$} \\
\hline & $\begin{array}{l}\text { City Hall } \\
\text { representative }\end{array}$ & 1 & & \\
\hline & $\begin{array}{l}\text { Former directors } \\
\text { of ruined } \\
\text { factories }\end{array}$ & 3 & & \\
\hline \multirow{7}{*}{$\begin{array}{l}\text { Personal } \\
\text { conversations }\end{array}$} & $\begin{array}{l}\text { Former workers } \\
\text { Residents }\end{array}$ & $\begin{array}{c}5 \\
10 \\
\end{array}$ & $\begin{array}{l}\text { Northern } \\
\text { Industrial Area }\end{array}$ & \multirow{7}{*}{$\begin{array}{l}\text { The subjects were randomly intercepted } \\
\text { and personal conversation were designed } \\
\text { as free conversation to capture the } \\
\text { individuals (former workers and residents } \\
\text { no-workers) perceptions on the local ruined } \\
\text { sites and on related aspects regarding their } \\
\text { opinions concerning the quality of life and } \\
\text { the urban landscape as well as their } \\
\text { position towards further regeneration. }\end{array}$} \\
\hline & Former workers & 5 & Southern & \\
\hline & Residents & 10 & Industrial Area & \\
\hline & Former workers & 5 & Central & \\
\hline & Residents & 10 & Industrial Area & \\
\hline & Former workers & 5 & Western & \\
\hline & Residents & 10 & Industrial area & \\
\hline $\begin{array}{l}\text { Inventory of } \\
\text { the local } \\
\text { derelict sites }\end{array}$ & & 1 & $\begin{array}{l}\text { All derelict } \\
\text { areas }\end{array}$ & $\begin{array}{l}\text { Based on personal observation and field } \\
\text { trip-research. The inventory is summarized } \\
\text { in Table } 2 .\end{array}$ \\
\hline
\end{tabular}


Table 2. Some basic data on local urban dereliction of the municipality of Lugoj (inventory made by the author, 2019).

\begin{tabular}{|c|c|c|c|c|c|c|c|c|c|}
\hline Area & Plants & Attested & Cultural Identity & $\begin{array}{c}\text { Industrial } \\
\text { Traditions } \\
\text { and Lost } \\
\text { Productions }\end{array}$ & $\begin{array}{l}\text { Preserved } \\
\text { Production }\end{array}$ & $\begin{array}{c}\text { Post-Socialist } \\
\text { Status }\end{array}$ & $\begin{array}{c}\text { New } \\
\text { Post-Socialist } \\
\text { Economies }\end{array}$ & $\begin{array}{l}\text { Types of } \\
\text { Ruins }\end{array}$ & $\begin{array}{c}\text { Commentaries Causes of } \\
\text { Dereliction or } \\
\text { Restructuring }\end{array}$ \\
\hline $\begin{array}{l}\text { Western } \\
\text { industrial } \\
\text { area }\end{array}$ & ITL Unit A & 1907 & $\begin{array}{l}\text { textiles } \\
\text { production }\end{array}$ & $\begin{array}{c}\text { textiles, } \\
\text { canvas and } \\
\text { Damascus }\end{array}$ & - & $\begin{array}{c}\text { completely } \\
\text { derelict }\end{array}$ & - & $\begin{array}{l}\text { industrial } \\
\text { ruins }\end{array}$ & $\begin{array}{c}\text { deindustrialization, plant } \\
\text { closure }\end{array}$ \\
\hline $\begin{array}{l}\text { Southern } \\
\text { industrial } \\
\text { areas }\end{array}$ & $\begin{array}{l}\text { Bricks } \\
\text { Factory }\end{array}$ & 1888 & $\begin{array}{l}\text { bricks production, } \\
\text { the factory was } \\
\text { founded by J. } \\
\text { Muschong, one of } \\
\text { the richest } \\
\text { business persons } \\
\text { in earlier } \\
\text { capitalism }\end{array}$ & bricks & $\begin{array}{c}\text { new types of } \\
\text { bricks to a } \\
\text { small extent }\end{array}$ & $\begin{array}{l}\text { derelict plant } \\
\text { to a large } \\
\text { extent }\end{array}$ & - & $\begin{array}{l}\text { industrial } \\
\text { ruins }\end{array}$ & $\begin{array}{l}\text { deindustrialization, plant } \\
\text { closure to a large extent }\end{array}$ \\
\hline \multirow{4}{*}{$\begin{array}{l}\text { Central } \\
\text { industrial } \\
\text { area }\end{array}$} & ITL Unit C & 1907 & $\begin{array}{c}\text { textiles } \\
\text { production }\end{array}$ & textiles & - & $\begin{array}{c}\text { completely } \\
\text { derelict }\end{array}$ & - & $\begin{array}{c}\text { industrial } \\
\text { ruins }\end{array}$ & $\begin{array}{l}\text { deindustrialization, plant } \\
\text { closure }\end{array}$ \\
\hline & $\begin{array}{l}\text { The Milk } \\
\text { Factory }\end{array}$ & 1942 & $\begin{array}{l}\text { cultural tradition } \\
\text { in casein and milk } \\
\text { products }\end{array}$ & food industry & - & $\begin{array}{l}\text { completely } \\
\text { derelict }\end{array}$ & - & $\begin{array}{l}\text { industrial } \\
\text { ruins }\end{array}$ & $\begin{array}{l}\text { deindustrialization, plant } \\
\text { closure }\end{array}$ \\
\hline & $\begin{array}{l}\text { The lasts } \\
\text { Factory }\end{array}$ & 1910 & $\begin{array}{l}\text { lasts and shoes } \\
\text { production }\end{array}$ & $\begin{array}{c}\text { lasts and } \\
\text { shoes }\end{array}$ & - & $\begin{array}{c}\text { completely } \\
\text { derelict }\end{array}$ & - & $\begin{array}{l}\text { industrial } \\
\text { ruins }\end{array}$ & $\begin{array}{l}\text { deindustrialization, plant } \\
\text { closure }\end{array}$ \\
\hline & $\begin{array}{l}\text { The rail } \\
\text { transport } \\
\text { area }\end{array}$ & 1970 & $\begin{array}{c}\text { connection } \\
\text { between industry } \\
\text { and rail transport }\end{array}$ & - & - & partly derelict & - & $\begin{array}{l}\text { rail } \\
\text { transport } \\
\text { ruins }\end{array}$ & $\begin{array}{l}\text { deindustrialization, the } \\
\text { failure of rail infrastructure } \\
\text { connected to the local } \\
\text { industry; }\end{array}$ \\
\hline
\end{tabular}


Table 2. Cont

\begin{tabular}{|c|c|c|c|c|c|c|c|c|c|}
\hline Area & Plants & Attested & Cultural Identity & $\begin{array}{l}\text { Industrial } \\
\text { Traditions } \\
\text { and Lost } \\
\text { Productions }\end{array}$ & $\begin{array}{c}\text { Preserved } \\
\text { Production }\end{array}$ & $\begin{array}{l}\text { Post-Socialist } \\
\text { Status }\end{array}$ & $\begin{array}{c}\text { New } \\
\text { Post-Socialist } \\
\text { Economies }\end{array}$ & $\begin{array}{l}\text { Types of } \\
\text { Ruins }\end{array}$ & $\begin{array}{c}\text { Commentaries Causes of } \\
\text { Dereliction or } \\
\text { Restructuring }\end{array}$ \\
\hline \multirow{7}{*}{$\begin{array}{l}\text { Northern } \\
\text { Industrial } \\
\text { Area }\end{array}$} & $\begin{array}{l}\text { The } \\
\text { Slaughter-house }\end{array}$ & 1912 & $\begin{array}{l}\text { cultural tradition } \\
\text { in } \\
\text { food-patri-mony } \\
\text { building }\end{array}$ & food & - & $\begin{array}{l}\text { completely } \\
\text { derelict }\end{array}$ & - & $\begin{array}{l}\text { industrial } \\
\text { ruins }\end{array}$ & $\begin{array}{c}\text { deindustrialization and } \\
\text { reindustrialization but } \\
\text { derelict }\end{array}$ \\
\hline & $\begin{array}{l}\text { Natural Silk } \\
\text { Mill (FMN) }\end{array}$ & 1907 & $\begin{array}{l}\text { cultural tradition } \\
\text { in natural silk } \\
\text { production } \\
\text { (unique in } \\
\text { Romania with } \\
\text { international } \\
\text { markets) } \\
\end{array}$ & natural silk & textiles & $\begin{array}{l}\text { restructured } \\
\text { but partly } \\
\text { derelict }\end{array}$ & $\begin{array}{l}\text { industry, } \\
\text { tertiary } \\
\text { activities }\end{array}$ & $\begin{array}{l}\text { industrial } \\
\text { ruins }\end{array}$ & $\begin{array}{c}\text { deindustrialization, } \\
\text { privatization, } \\
\text { mismanagement plant } \\
\text { closure, fragmentation, }\end{array}$ \\
\hline & IURT Plant & 1970 & $\begin{array}{l}\text { state-socialist } \\
\text { plant }\end{array}$ & machinery & machinery & $\begin{array}{l}\text { restructured } \\
\text { and partly } \\
\text { derelict }\end{array}$ & $\begin{array}{l}\text { machinery, } \\
\text { shoes }\end{array}$ & $\begin{array}{l}\text { industrial } \\
\text { ruins }\end{array}$ & $\begin{array}{c}\text { reindustrialization, } \\
\text { tertiarization a part of it was } \\
\text { privatized through } \\
\text { Romanian capital, while } \\
\text { other part was purchased by } \\
\text { Rieker, reindustrialization. }\end{array}$ \\
\hline & IUPS Plant & 1974 & $\begin{array}{l}\text { state-socialist } \\
\text { plant }\end{array}$ & spare parts & spare parts & $\begin{array}{l}\text { restructured } \\
\text { and partly } \\
\text { derelict }\end{array}$ & $\begin{array}{l}\text { machines } \\
\text { spare parts }\end{array}$ & $\begin{array}{l}\text { industrial } \\
\text { ruins }\end{array}$ & $\begin{array}{l}\text { in the beginning, the plant } \\
\text { was privatized through } \\
\text { Romanian capital }\end{array}$ \\
\hline & $\begin{array}{l}\text { The brick } \\
\text { factory }\end{array}$ & 1888 & $\begin{array}{l}\text { cultural tradition } \\
\text { under earlier } \\
\text { capitalism }\end{array}$ & bricks and tills & - & $\begin{array}{l}\text { completely } \\
\text { derelict }\end{array}$ & - & $\begin{array}{l}\text { industrial } \\
\text { ruins }\end{array}$ & $\begin{array}{l}\text { deindustrialization, plant } \\
\text { closure }\end{array}$ \\
\hline & $\begin{array}{l}\text { Mondial } \\
\text { Plant }\end{array}$ & 1900 & $\begin{array}{l}\text { cultural tradition } \\
\text { in materials for } \\
\text { constructions }\end{array}$ & - & $\begin{array}{l}\text { sanitary } \\
\text { products }\end{array}$ & functioning & $\begin{array}{l}\text { sanitary } \\
\text { production }\end{array}$ & - & $\begin{array}{c}\text { reindustrialization, } \\
\text { privatized through FDIs, } \\
\text { completely purchased by the } \\
\text { German Company Villeroy } \\
\text { and Boch }\end{array}$ \\
\hline & $\begin{array}{l}\text { Military } \\
\text { Area }\end{array}$ & 1960 & $\begin{array}{l}\text { important } \\
\text { military site } \\
\text { under } \\
\text { state-socialism }\end{array}$ & $\begin{array}{l}\text { sanitary } \\
\text { products }\end{array}$ & - & $\begin{array}{c}\text { to a large } \\
\text { extent derelict }\end{array}$ & - & $\begin{array}{l}\text { military } \\
\text { ruins }\end{array}$ & $\begin{array}{l}\text { cities' demilitarization, since }^{\prime} \\
\text { the Romania access to NATO } \\
\text { and professional army. }\end{array}$ \\
\hline
\end{tabular}


Useful photographs, repeatedly taken [90] in the ruin research, related to the results of qualitative research in urban areas, triangulate the findings of the study. In all, the recommended methodology on urban ruin research $[1,2,6,8]$ was followed to understand the (re)production of urban derelict places, their main consequences as well as their social and cultural implications in the local community.

\section{Results and Discussion-Urban Dereliction as Part of the Romanian Postsocialist Urban Formation}

The Romanian postsocialist urban formation is controversial and unequal, having both positive and negative consequences in the spatial patterns of the cities and community life. The national de-/reindustrialization and the relocation of industry [56,81], through privatization of the former socialist industry and its related sectors, reshaped the urban patterns, thereby generating urban dereliction with evident ruins in all Romanian cities $[30,46]$. This dereliction, which is related to the national, regional, and local identity, altered the domestic, industrial culture [52,91], and the local communities' welfare and identities [18,56,62,92-94].

\subsection{Ruins of Postsocialist Romanian Cities}

A review of the postsocialist transformations in Romania shows that transition to a new post-90 capitalist order largely ceased the previous industries. The industrial collapse and deindustrialization profoundly affected Romania, just like other different postsocialist EECs [28,36]. Consequently, many national, famous brands and domestic production, and some of the largest Romanian plants in Europe, disappeared in the face of globalization, as a matter of wrong privatization and in the absence of sustainable visions in the postsocialist policies in economic restructuring. The national privatization also faltered because of the fragile background of the new economic transition with no suitable industrial policies in the national economic restructuring. The absence of a suitable legislative background as well as of appropriate visions and regulation regarding the integration of local goods into international markets contributed to a faulty privatization, massive unemployment in the face of international requirements towards national industrial restructuring [95], unstable and conflicting political decisions, faltering economic reforms, speculative actions in privatization, corruption $[53,96]$, new real-estate developers' interests, and the absence of national policies for domestic, industrial production and industrial, cultural heritage preservation $[26,36,97]$. A wide range of media channels unveiled these issues $[98,99]$.

These factors are related to the post-90 flows of globalization constraints on the states' power, by improving different tools in industrial policies $[100,101]$. The postsocialist changes in the former socialist inherited industries had negative impacts on the local communities, generating differentiated patterns and landscapes $[28,102,103]$. Due to national deindustrialization, Romania now has huge areas of industrial ruins and derelict places-appreciatively, one billion $\mathrm{m}^{2}$, with contaminated areas. Of these, more than 1800 ruined sites are critically polluted with chemicals used in the former state-socialist production. They appear in the inner-core of the cities and in the peripheries, threatening the local communities with no knowledge of these potential risks. For more than twenty years, the issues of industrial derelict places shifted from one government to another, portraying ignorance and allowing ruins to simply exist in their apocalyptic landscapes [104], real neoliberal landscapes of deception [105].

Industrial ruins of the former state-socialist industry decline, appeared throughout Europe and Romania from Bucharest, the capital of Romania [30-32,39], to the second-tier cities [40,62,93,106-108] and to mono-industrial or small- and medium-sized towns $[18,41,56]$. Currently, from 14 steel plants, only one operates and it greatly reduced its capacity [109]. While in other former European communist countries, the state-socialist industrial sites were reused, in Romania, through improper policies in urban planning, they remain largely abandoned, unveiling the governments' ignorance from the national scale to a local level $[110,111]$. According to an interview with a former engineer in a large industrial plant in Brasov, Romania, this reality is grounded in the unproductiveness of the former industries in the conditions of the new capitalist order, unfitting to the new postsocialist markets [112,113]. This is, however, paradoxical as long as many Romanian products had large markets all over the 
world in the past, with Romania being an important industrial country in Europe. While totally blaming the former state-socialism, the interest of the national governments was to bankrupt the Romanian industry, by providing certain sources of enrichment of involved actors in the so called "privatization"-politicians, foreign and domestic investors, developers, and others. Twenty-five years after the state-socialism collapse, between mismanagement, ignorance, theft, and personal interests, none of the national governments took responsibility for what was done, regarding the current dereliction [109]. At the same time, Romanian postsocialist governments have not sold only industries (plants, factories, and mills), through controversial privatization, but they destroyed the national markets, according to an interview with a former Director of a trading company in Lugoj. In Romania, as in all Central Eastern Europe, appeared transnational companies, with industrial relocation being a crucial action in the postsocialist reindustrialization $[6,56,86,87,113]$, favoring Greenfield investments in new industrial sites. Consequently, the former state-socialist areas remained derelict and redundant, but are real sources for new owners' enrichment (through the scrap selling for money), or for poor scavengers, saving their daily subsistence by scrap theft $[109,114]$ Furthermore, industrial ruins remain unsafe sites, threatening local communities and altering the material culture of the Romanian industry.

In conclusion, the algorithm of the former state-socialist industries' ruination are as follows: The state-owned factories and plants after the year of 1990 accumulated significant debts to their suppliers at the beginning of the 1990s. As a result, they were sold, divided, and re-sold. The new owners were unable to make them competitive and, consequently, the firms became insolvent and eventually became bankrupted. Then, industrial plants and factories were dismantled and sold as scrap metal by domestic or foreign owners. This was the tragic destiny of hundreds of Romanian factories, unveiling the helplessness of the Romanian government to manage proper policies for economic and urban restructuring, as well as their indifference towards emerging ruins and the cultural traditions in Romanian industry. In other words, the Romanian liberalism promoters destroyed the national industry, which translated into bad living conditions for local residents in industrial neighboring districts. Related to deindustrialization, ruins appear in rail transport sites due to the industrial decline and to the close connection between industry and rail transport system [85]. Privatization of the transport sector was another factor in the production of the rail-ruined places. Derelict places arose in the residential districts and in their related facilities, because of social and economic restructuring. Considering the political and military changes in international cooperation and cities' demilitarization, ruins appeared in the former military sites, since Romania had access to NATO. This national scene of urban dereliction translates to lower levels, with particular consequences and specific social and economic implications [19]. The next section unveils the urban dereliction in the nonmetropolitan areas, with the municipality of Lugoj sampled as a case study. It explains the urban ruins (re)production and their impact on the local community.

\subsection{Investigating Local Urban Dereliction in the Romanian Small-Sized Towns: The Case of Lugoj Municipality}

The municipality of Lugoj is located in the western part of Romania (Figure 1) and it is known for its industrial traditions. In 1992, it had a population of 51,827 inhabitants. This number continuously decreased during the postsocialist period; in 2002 it was 47,027 and 46,858 in 2019, respectively. In 1992, Lugoj had 20,659 employees of which 11,407 (55.46\%) were employed in the industrial sector. The process of the local industrial restructuring strongly influenced the labor in industry to 7107 employees $(51.12 \%$ ) in 2002. By 2011, there had been a minor increase to 9424 . The unemployment rate was $6.43 \%$ in 2002 and $3.43 \%$ in 2011 [115,116]. These industrial employment trends, as well as the total unemployment rate, illustrate the local adjustment of the industrial restructuring process to the new market oriented conditions of the local economy. In cases where new investments did occur they tended to develop industries in new areas, marginalizing the old industrial areas of the town. They remained unused, abandoned, and turned into ruined and derelict sites. Consequently, under postsocialism, the Lugoj municipality was faced with important derelict areas [56]. They were symbolic places in the city's local industrial culture and local history. Urban ruins are the results of 
postsocialist urban restructuring fueled by the former state-socialist industrial decline and by the new post-90 capitalist order.
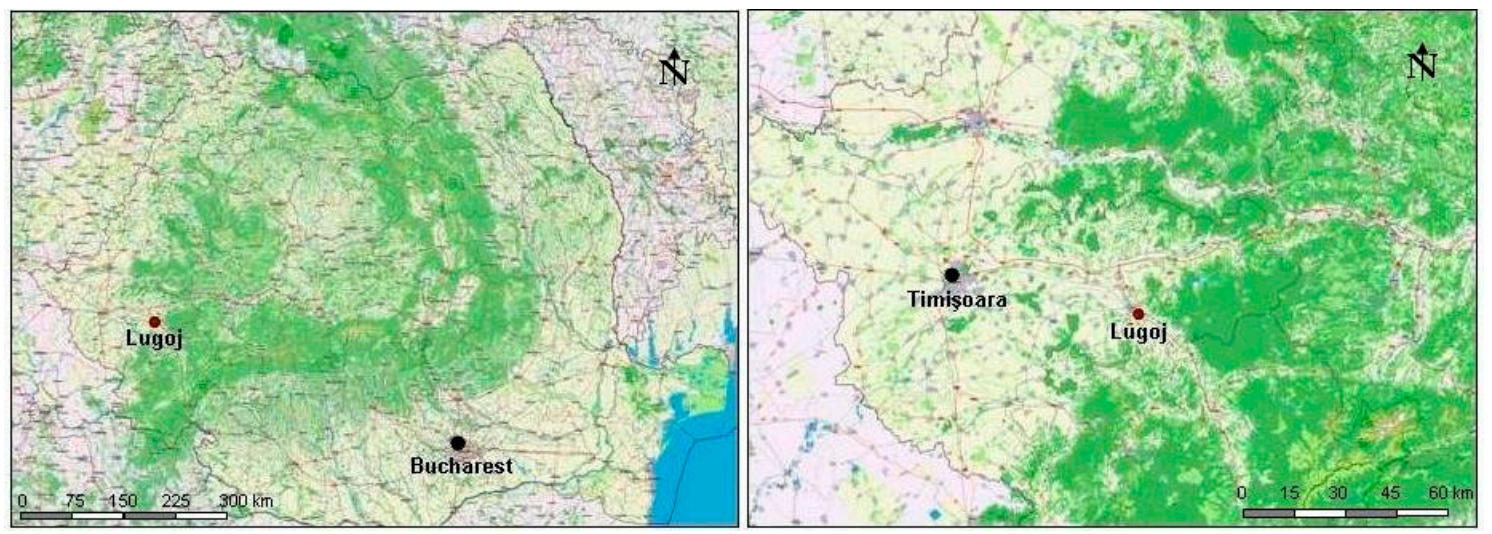

Figure 1. The location of Lugoj municipality in Romania and Timiș County.

Industrial ruins. The narrative concerned with industrial ruins (Figure 2), highlights two important accounts: completely derelict industrial areas and partly derelict industrial places, in functioning industrial areas. Major derelict industrial areas appeared in the southern, western, and central parts of the town, while partly derelict spaces are found in the northern industrial area [56]. These cases illustrate fewer opportunities that abound in the local urban regeneration, through new capitalist urban interventions and local urban regeneration programs. With the postsocialist industrial restructuring, the residential districts and neighboring industrial areas underwent important social decline, currently prevalent in residential areas [117]. To assess local dereliction, an inventory of the ruined sites has been made, with the main findings illustrated in Table 2. The results unveiled that all factories with old cultural traditions were bankrupted, closed, and finally ruined. Against such a background, important traditional industries passed away, altering the local cultural economies, with industrial ruins left behind [56]. Data included in Table 2 emphasize important features, actions, and outcomes in local industrial restructuring, under the post- 90 umbrella of market economy, with ruins standing as proofs of the postsocialist industrial restructuring at the local scale.

On the one hand, it is important to note that all industrial plants and their related facilities appeared under the earliest capitalism were bankrupted during postsocialist privatization, reminding the local traditional industries only through their ruins. On the other hand, under the post- 90 economic restructuring umbrella, some of the former state-socialist plants were partly restored through domestic and Foreign Direct Investments (FDIs). Furthermore, through fragmentation due to the multiple interested stakeholders, sections of those plants were partly renewed while others turned to dereliction. A reason for these actions is grounded in the competitiveness of both machinery and automotive industry in Romania [118]. This industrial field was of interest as long as it could make use of the local cheaper labor force. In the same vein, another successful industrial field in state-socialist plants restructuring was sanitary ceramics manufacturing, with a continuous tradition in inner-housing environments, as it was the light industries focused on textiles and shoes production. These industries reframed to a smaller and larger extent the former state-socialist plants with few interventions in the regeneration of local, traditional industrial plants. 


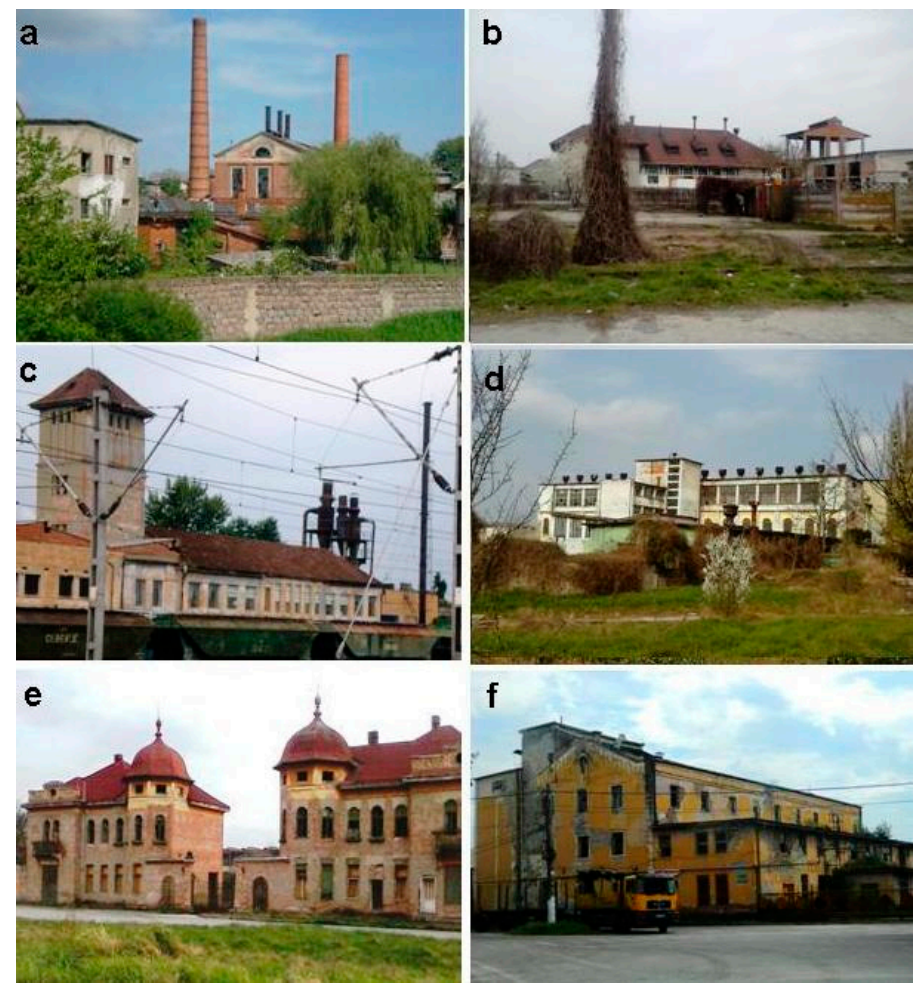

Figure 2. Derelict industrial places in the municipality of Lugoj: (a) Textila factory, (b) Milk processing factory, (c) Shoes and lasts factory, (d) Natural silk mill, (e) The Slaughterhouse, (f) Clara mill (photos taken by the authors 2015-2019)

Although post-90 industrial investments in local economy were from areas of local tradition, most of them were designed in new industrial sites, with new plants and factories opened. Therefore, the regeneration of the former industrial estates was a neglected process. Against such a background, an uneven spatial development in the local industry arose with different types of interventions. Firstly, the restructuring and regeneration of the old, local, and traditional factories were ignored. Secondly, only a part of the former state-socialist factories were of interest to the new post-90 investors, with uneven actions in their refurbishment-while others were entirely refurbished, other plants were partly restored, with important ruined sites left behind [56].

Thirdly, new industrial investments in local industry, generated new industrial sites with no interest in the previous factory's restoration, although, their profile measured up with the failed traditional factories [56]. Thus, the local (re)production of urban dereliction remains a postsocialist process, fueled by the transition to a market economy, and by different stakeholders' indifference towards the local, traditional, and industrial estates.

Particularizing the local ruins' discourse, the narrative of the local urban dereliction, introduces some typical and emblematic samples. For instance, the case of the former textile industry plants is relevant. At a time, they were emblematic buildings with related facilities for their hundreds of employees, working in three shifts per day. Based on cotton from Africa, it produced appreciated canvases that were produced and sold in many parts of the world, because of their quality and convenient prices. Until the year of 1990, everyone searching for work found not only a job here, but also other social and cultural facilities. The workers received an apartment in the neighboring district. This plant encountered a massive decline after the year 1990, being rapidly bankrupted. For more than 15 years, the plant has been in ruin (Figure 2a). The former workers still living in this area advocate for its bad and speculative privatization. "For as long as there are large interests in selling the former factory and its equipment for reasonable amounts of money, who cares about this old factory or local textile culture?" (Interviewee: D. A./female/56.) 
Other talks with former workers reveal that the privatized factory was dismantled, sold as scrap, remaining only the current ruined walls. The postsocialist interests were to sell the former socialist industry. In all, privatization destroyed the local culture of industry. This factory could be reborn under the new capitalist rules or it could host a textile museum [119], but, "who cares, for as long as it can still be ignored, remaining an abandoned place, subject to indifference. From a successful factory, this place became repulsive, as it is an isolated place neighboring a slum." (Interviewee: A. M./male/62.)

An appropriate story fits to the southern industrial area, hosted the Brick Factory, founded by J. Muschong, one of the richest capitalist businesspersons in Lugoj, under the early stages of capitalism. Compared with J. Ford from America, and the owner of a large industrial empire in the western part of Romania Muschong built the factory in the year 1888 [56], producing high quality bricks and tills, sold in all of the Austro-Hungarian Empire and Romania. Under the state-socialism, the factory was nationalized in 1948. Its production targeted the massive real estate development in the Romanian cities hosting the migrant rural population. Privatized after 1990, out of hundreds of employees few workers were retained to a small extent; the factory uses the former industrial facilities. Large parts of the factory turned to ruins. This emblematic factory remains largely ruined, destroying the local industrial traditions, altering the landscape, and entailing its neighborhood decline. The residents in this area live at a subsistence level in old and derelict houses (Figure 3) with low incomes and social support $[116,120]$.

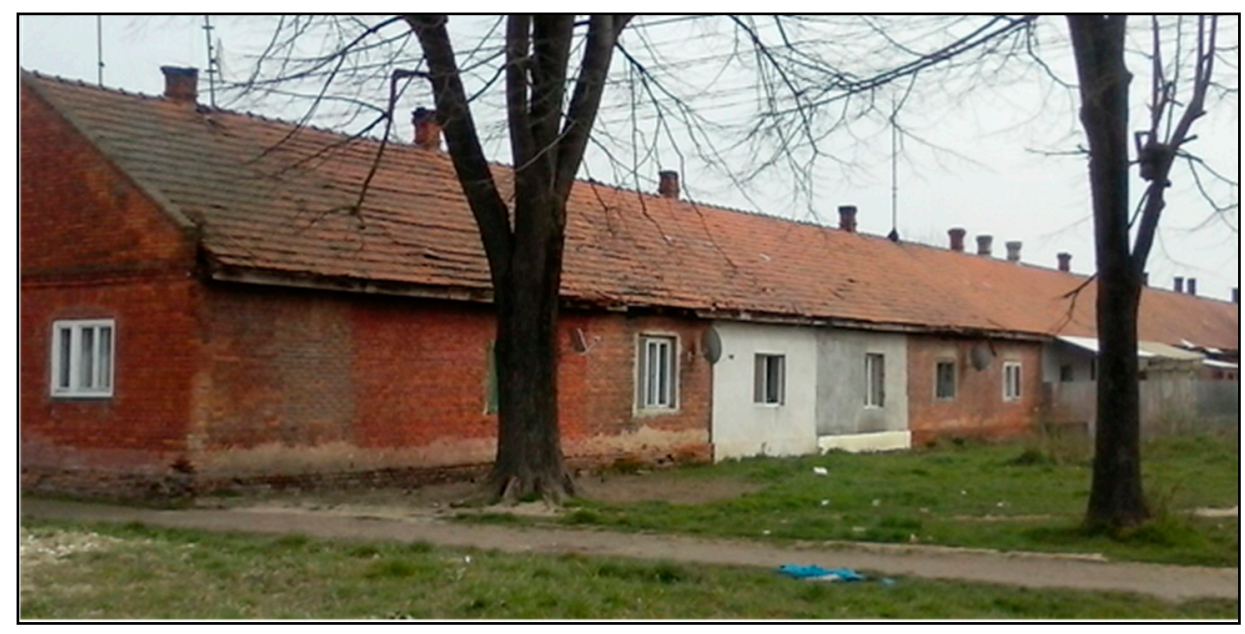

Figure 3. Poor houses in the proximity of derelict and ruined sites of Lugoj: an example from the southern industrial area (photo taken by the authors, 2019).

According to the conversations conducted with the Social Assistance representatives, the local authorities support more than $80 \%$ of the families living in this district. Evidences of other samples are from various old industrial plants. The milk-processing factory, built in the year 1942, was an important manufacturing company in the national food industry. It was the sole producer of casein sold in Italy, processing milk in a variety of products for a large Romanian market. Had it only been for the local and regional demands during the post-90 period the factory would have been worth operating. Privatized between 1990 and 2001, it encountered important debts, being further bankrupted and ruined (Figure 2b). In 2005, AVAS (The Romanian Authority of Administration the State Assets) sold this plant for only USD 230,000 to RomInox SA Romania, (further HandInox SA, Romania). Closed in 2013, it was purchased by the Energy Company USA\&RO Romania administrated by the daughter of a former director of The Romanian Railway Company Timişoara, a controversial person in both politics and business. The price of this transaction is, however, interesting; although the plant occupied $5000 \mathrm{~m}^{2}$, it was of only $€ 75,000$. The new owner intended to restore it for commercial services [121] but up to now, the place is still derelict. This evolution points to private interests in local 
privatization. About all these, there is a prevailing regret of the neighboring residents, regret about what once used to be there, blaming the bad postsocialist industrial restructuring.

"Since the year of 1972, I have lived and worked here. The factory operated properly before and after 1990, but its survival chances are considered compared to the new national and international milk producers. It could function with a good management. I think its failure was deliberate. All equipment was removed. The scrap-selling center is just around the corner. Since the year 2000, the factory has turned to ruins as its neighboring rail area. This part of the town is desolate with repulsive landscapes. Looking around, we could find: ruins hosting waste, stray dogs, homelessness and high weeds, everywhere ... Does someone in our government care about this ruined place? I don't think so. Yet, these ruins are a part of our everyday life." (Personal conversation: P.I./male/66.)

However, in this area, nothing happened. The factory is still in ruin without any intervention for its restoration. On the same platform next to the milk processing plant, there is the last factory, with old national tradition in shoes production. Its post-90 bankruptcy is due to the local authorities' lack of preparedness, in the face of the new postsocialist market economy. From a successful manufacture, the plant is in now in ruins (Figure 2c). In the early postsocialism, the factory operated properly. In 1998, it was privatized and its decline began in 1995. Four years later, a company from Timişoara purchased it. With the new market economy demands, it was difficult to manage a large socialist plant. It lost its markets and it could not adjust its production to the new competitive requirements. Because of uncertain political circumstances and lack of transparency in the business sector, the foreign investors were skeptic to invest in Romania. In the situation they decided to invest, they did so basically in Greenfield rather than restoring Brownfields. It was Rieker-the transnational company that took over the old shoe factory assets. To conclude with the words of a former engineer, the shoe factory "privatization was a huge mistake for the former state-socialist factories." (Interviewee/former engineer/B. D./52/male.)

On the industrial platform between these factories, a large derelict railway area speaks for the past importance of rail infrastructure in the local industrial functionality. Most of the ruins emerged after 1997. The post-2000 maturity in local and national economy [118] partly revives the former state-socialist, industrial areas. In Lugoj it is the case of the northern industrial platform that triggered the interest of important transnational companies, such as Villeroy and Boch, Rieker, MPV Gmbh, and located themselves in some of the former state-socialist plants that were restored to different extents. Thus, some parts of the industrial platform were also ruined. Of these, FMN (The Natural Silk Mill) (Figure 2d), and the Slaughterhouse (Figure 2e) are relevant. The latter, declared monument, with an important cultural tradition that prevented its transformation [122] remains derelict. FMN), which was unique in Romania and with a large worldwide market, ended its natural silk production in 1990. Concerning its post-90 privatization, a former engineer stated:

"In 1995, some Japanese investors intended to purchase and modernize the factory in order to continue the natural silk production, but the deal with Romanian authorities failed. Nobody knows the reason for this. Furthermore, a Romanian investor purchased it at a low price. It was then, divided; some parts were sold, put on let or turned to services. However, its most backward part is ruined." (Interviewee/formerly engineer/L. D./62/female.)

Thus, the natural silk production failed, and so one of the traditional industries in Lugoj passed away. In addition, all its assets—the machinery-disappeared. A former worker remembers: 
"I remembered in the 90s, that the natural silk section has been dismantled. All the stainless steel equipment has been loaded into huge trucks. I think it was sold as scrap, making the new owners richer. Since I was 18 years old, my life has been connected to this plant. Then, I lost my job, as the town lost one of the most prominent factories. Sometimes, I still watch the ruins, regretting what was once there. As a dismissed worker after 25 years of work, my husband and I had to commute $60 \mathrm{~km}$ away, in Timişoara for new jobs, because at that time, no one hired us in Lugoj. We still regret the failure of the plant." (Interviewee: I.J./female/62.)

Considering un-participatory actions and the helplessness of the dismissed workers, a former employee in the plant stated that: "There was nothing to do, as we could not decide the future of the factory. Even as workers for three decades in the plant, we could not protest. This is the new capitalism ... For some individuals, a godsend for enriching, for ex-workers, remain only regrets towards these ruins." (Interviewee: E. P./female/67). In the same vein, the ruins of Clara Mill (Figure 2f), also reflects the mismanagement in local privatization, delays in local regeneration, unknown owners and heirs, complex processes in the Romanian redistribution of land and nationalized estate [123,124], and lengthy lawsuits for the ownership of the ruined factories. This led to the loss of the local industrial tradition. An old guardsman looking at the ruined building said: "I used to work here all my life. This mill was once the granary for Western Romania, as Romania was the granary of Europe. Now, all that you can see are ruins, as all old Romanian industry is ruined." (Interviewee: P.V./male/68.). Meanwhile it was partly restored. The voices of the local residents frame the judicial context of urban dereliction. This context is rife with legal uncertainties, for instance, with regard to ownership titles and investments, which explains why the urban regeneration can often times not be a kick-started process. On the other hand, dubious processes of privatization are responsible for the present ruins. In addition, the lack of action by local authorities is explained, and is based on ignorance and indifference relating to intimate connections between local (corrupt), political, and (predatory and speculative) business elites (usually members of the same families and former communist cliques), who have only their own private interests in mind [18]. The blame for the present urban dereliction and industrial ruins falls equally on both the local government and the local and foreign capital, infused in the creative and brutal destruction. Processes such as industrial delocalization, plant closing, foreign direct investment [118], and free trade agreements are responsible for the locally ruined sites. Furthermore, mismanagement, and ignorance led to the ruins production. Wrong interventions and bad strategies in postsocialist urban planning are also responsible for the industrial urban dereliction in nonmetropolitan Romanian areas.

Ruins of rail transport decline. Ruins of railway network relates to the industrial decline. Both under capitalism and later under state-socialism, the industry was connected to the rail transport network because it was the main facility used in raw materials supply and in the distribution of local production. Consequently, disused railway networks [125], are currently neighboring derelict's industrial places and their related facilities [85]. Such is the case of Lugoj, where all the former state-socialist industrial areas now include rail transport ruins (Figure $4 a, b)$. At the same time, with the postsocialist restructuring of the national railway transport system, associated with the local decline in the state-socialist industry, the rail freight registered important regresses and large ruined areas of rail facilities, which neighbored the railway station and industrial areas. They are now abandoned places close to the city center, and to residential districts, thus, threatening the local community. With respect to urban regeneration, they captured the local authorities' attention. When drawing the recent master plan of the town, the local government decided to remove disused and abandoned rail infrastructure. It was a local proposal to the Ministry of Transport in Bucharest. In this regard, the interview conducted with a representative of the Urban Planning Service of the town unveiled that, "we followed the legal procedures with the Ministry of Transport to restore the ruined rail sites, but we did not receive any consent regarding our proposal. The national government considered local rail infrastructure as sites of national interest. What is the interest about them, as long as these sites are still abandoned and ruined, and are still subject to continuous degradation?" Against such a background, it seems that local decentralization is rather 
theoretic, arguing conflicting relations between centralized state power and local decentralization in urban planning [126].

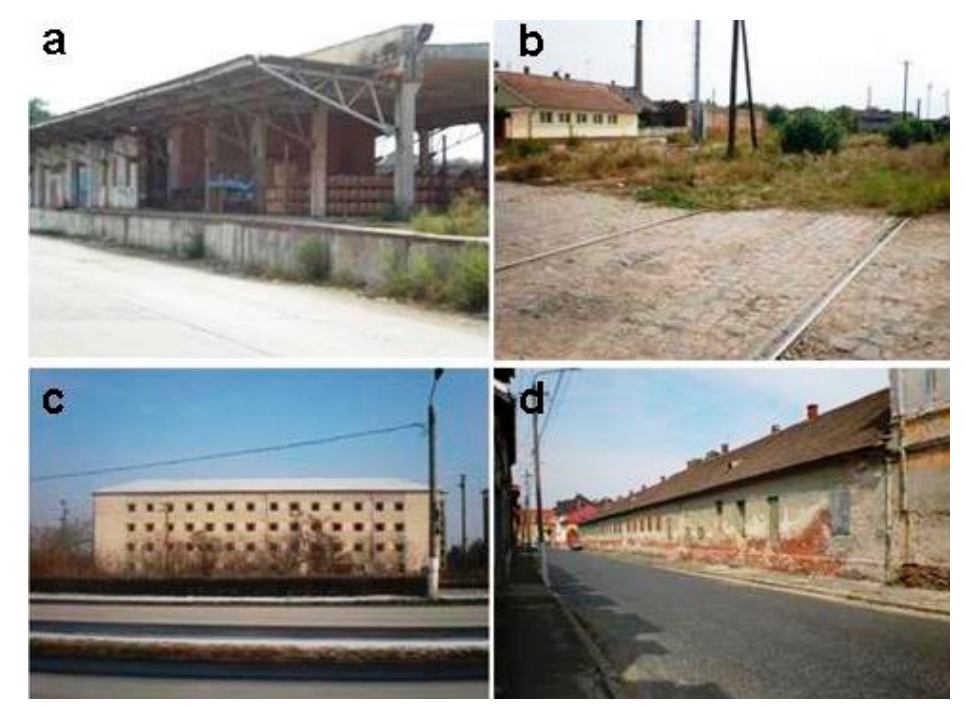

Figure 4. Local derelict transport areas (a,b) and military derelict sites (c,d) (photos taken by authors 2018).

Cities' demilitarization and ruins of the former military sites. Derelict places emerged because of the Romanian military restructuring (Figure 4c,d). From this perspective Lugoj played a major role in the defense of the western border of Romania-under the Warsaw Treaty-hosting one of the six Romanian mechanized divisions equipped with 9M21 LUNA-M missile, which had a maximum range of $70 \mathrm{~km}$ being designed to carry explosive, nuclear, chemical, or instruction charge [127]. Eventually, they were withdrawn in 1995 as a result of the Treaty of Medium Range Nuclear Forces (1987, Washington). The crucial moment in the de-militarization of the town and formation of military ruins was caused by the policies of Romania's access to NATO after the debates of the Summit in Prague in 2002. Consequently, in 2004, Romania had full access to bases for a professional army. Since 2006, the military service has become unbounded, with many employees in the military system, unduly retired and with military bases largely reducing their activity or by becoming decommissioned. According to interviews with three former colonels in the local military units, the military sites in Lugoj that were abandoned are subject to degradation. Of these, two sites are relevant: The military unit in the peripheral area of the town and the army barrack in the inner-core of an urban area. The first remains abandoned and subjected to degradation since the year 2006. Being under the state's ownership, The Council of Timiş County set it up for sale. Different investors showed interests in purchasing this estate for services and residential purposes. Nevertheless, the deals failed. Currently, this site is on the agenda of the local government, with projects in pole position regarding its restoration for residential and service purposes. With no funding, the projects are only theoretical. The community's voice concerning this issue, advocates for new residential facilities, especially for poor or young families with low incomes. Nevertheless, the problem is forwarded to the regional and local government for further decisions. The last argued the need for new houses; this area required ecologic cleaning before further investments. Regarding residential conversion, a protocol between the City Hall in Lugoj and the Ministry of National Defense in Bucharest, was stated, but was further blocked [128]. However, this site remained derelict. Despite these in-between approaches, theoretical, abandoned and stand-by projects, debates, and negotiations, in the absence of financial funds or urban development funding projects, this site remains derelict. The second derelict military site follows the same pattern-left in ruin in the inner-core of the town with a large potential for regeneration. In addition, since this place contained military buildings belonging to the Habsburgs Empire, it portrays an important cultural 
heritage. At some point, a private association showed interest in restoring this estate, but the initiatives failed, with this place remaining derelict, as other buildings in the inner-districts [129].

Ruins in residential areas. The most important derelict places in the residential neighborhoods are the former heating plants. In the case of Lugoj, they are sites damaging the safety and the image of the districts [123]. Designed under state-socialism for the centralized heating system, they became ineffective during postsocialism, due to their old equipment and distribution infrastructure. Water and heat were supplied intermittently (heat twice a day during the cold season and water three times a week for a few hours). These low services doubled by major heat losses due to the old infrastructure, on top of bad living conditions and high charges for improper residential maintenance, prompted the flat owners to assemble individual heating systems in their apartments. Since the year 2003, more than $75 \%$ of the housing units installed private heating equipment; in 2008, the individual heating systems were being installed in 95\% of the apartments in Lugoj. In addition, all these were installed in the absence of financial aid from the municipality. Most residents installed their own heating system through bank credits. It was not a simple investment, but it ensured an improvement in housing of the residents. It was more suitable to pay their credit rates to benefit from proper heating services in their houses, rather than supporting high costs, for improper centralized services. Thus, the heating plants in districts became redundant [123]. Being ceased and abandoned, they turned to ruins. The inside equipment disappeared and all useful materials bringing any gain to scrap scavengers were stolen and sold. These former heating plants generated repulsive landscapes, thus, posing a threat to neighboring residential areas and their safety. They are now places hosting residual waste, sheltering the homeless, and stray dogs. They are obsolete places in the inner districts. Typical samples are the ruins of heating plants in districts Micro I (Figure 5a), Micro IV (Figure 5b), and Micro III (Figure 5c,d).
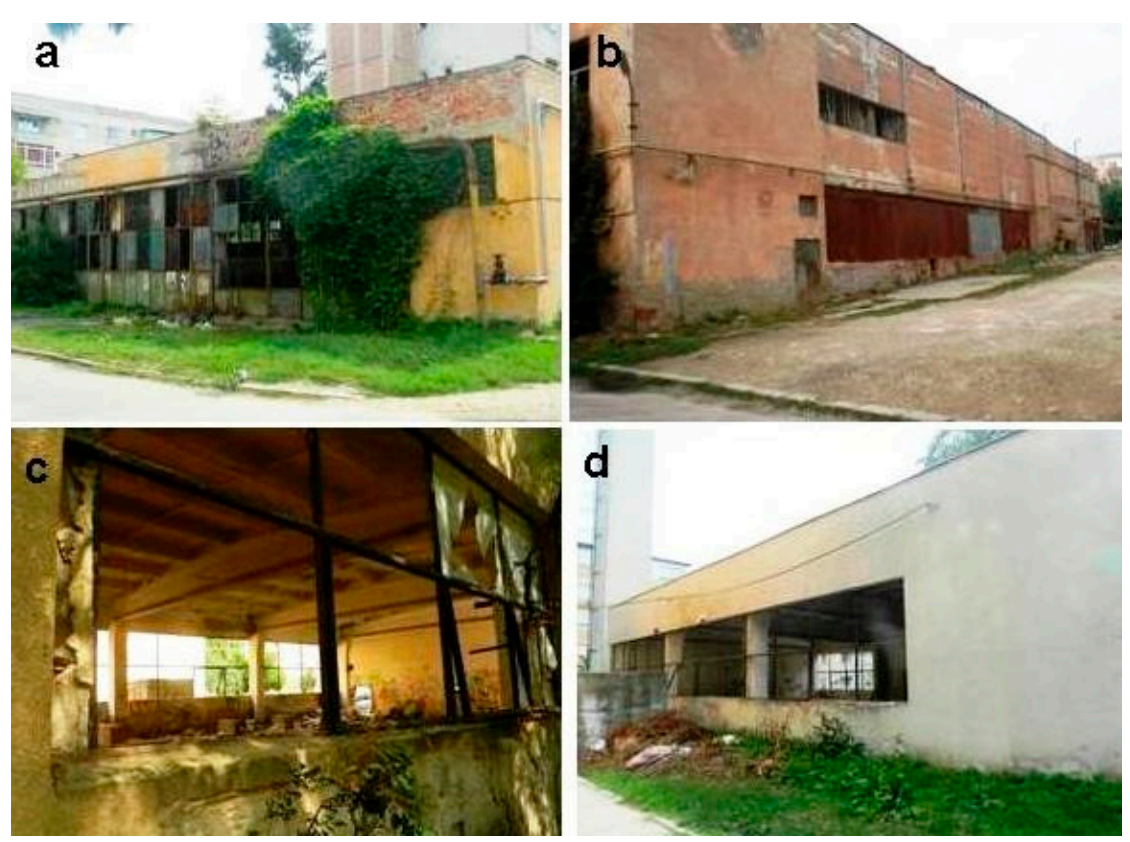

Figure 5. Derelict places in local residential areas: abandoned heating plants in the inner districts of Lugoj municipality: Micro I (a), Micro IV (b), Micro III (c,d). (photos taken by authors, 2015-2019). 
A glance inside the latter ruined place, revealed cruelty destruction, figuring these places as the ones for waste storage. A former plant administrator stated:

"I used to manage this plant for twenty years. In the year 2002, based on a local government's decision, it stopped operating like the others in town. They became redundant, since private heating systems were installed in blocks of flats. Being under local municipality administration, but at the same time, in the care of no one, soon its equipment disappeared. I am sure it was sold as scrap. The plant was further vandalized and became a ruin with a repulsive image, sheltering homeless, stray dogs and waste. With the plant closure, I lost my job just like my colleagues. I live opposite it, I saw it degrading every day, and I regret that the authorities did nothing with the ruins that harm the inner landscape of this neighborhood." (Interviewee: M.N./male/65.)

Owned by the local administration, the former heating plants such as the derelict spaces reveal the indifference of local authorities and of those vandalizing these places [123]. The discontent of neighboring residents is evident:

"I see the ruin of this heating plant, every time I look through my window. Instead of seeing, an enjoyable landscape, I see this wasteland and repulsive place hosting stray dogs and homeless people fed and cared by different tenants. I am afraid of this place. In summer, the smell of the waste inside it is terrible, so I cannot even vent the house. If my living conditions were favorable, I would sell my current apartment and move elsewhere." (Interviewee: K.B./male/44.)

The negative consequences on the residents' quality of life translate to risky and unsafe conditions. The issues of stray dogs—as a major problem in urban Romanian areas [130]—and of homeless hosting in these ruins are acute at the local level [123]. They are rather in the care of the neighbors than being in the care of the local institutions. To some extent, the local municipality ignores them. Another talk with a local tenant reveals the following opinion:

"I do not understand why the local authorities do nothing with these ruins. The town needs social houses and these buildings remain vacant. Rather than hosting the homeless, they could turn to social housing, for poor families. Of course, these actions require important financial resources, but the local government has to take this issue seriously because there are many opportunities to apply for EU funding for local housing. I think there is too much ignorance, while viewing local dereliction." (Interviewee: P.L/female/39.)

Considering the instance where socialist districts with blocks of flats and their facilities were designed only for working class reproduction [93], and their postsocialist redundant places could change into different useful facilities for inhabitants, I. E./48/female stated that, “Our children often play nearby or even around these unsafe plants. These ruins from former heating plants and even those from industrial sites could turn into playgrounds, green spaces and recreational places for children and local residents." As expected, the community's voice advocates for restoration of local derelict places, often ignored by the local government, although these voices could be heard the un-participatory interventions of the local community are obvious. This idea unveils that urban ruins could be seen as sites of opportunities with a positive dimension in the local urban nature and in the town regeneration [131]. Particularly in the case of Lugoj, the ruined site of the rail transport area could turn into a green area or park considering its location next to the center of the town. The urban derelict areas in the inner districts of the town could be developed as facilities for the residents, as parking places, or other urban services. Then, as was mentioned before, the unused military buildings could be turned into social housing estates for the local residents, while other derelict areas of the residential districts could be restored and used as playgrounds and so on. Obviously, there are multiple opportunities for restoration. Some of them captured the local authorities' attention, but three decades after the state-socialist breakdown such projects either remain elusive or develop at a very slow pace. 
Ruins restoration, still an illusion for local community. The legal framework in urban regeneration related to the restoration of historical buildings is based on Law No. 50/1991, Law No. 422/2001, and Law No. 153/2011, respectively, assumed by the Romanian Parliament. In addition, the Decision of Local Council, No. 213/2011, forced the current owners to restore derelict sites, especially those with important cultural and historic values. This issue is included in the framework of the local strategy of urban development, but they are rather theoretical than functional. Since 2010, when the local strategy for urban development has been designed, nothing happened regarding the towns' ruins. In many cases, the owners of the current derelict sites are unknown [41], or their tenures are doubtful and ambiguous. Ignorance of the local urban development policies and real estate speculations, related to the reinforcement of the real estate market, are important contributors to the postsocialist production of urban ruins. Those with cultural treasures of the past, claim it for further regeneration, both for the local community development and for the cultural and historical building preservation. More than ten years after the first legal rule, and after four years since the local decision was taken, in the municipality of Lugoj, nothing has happened. Furthermore, the local government states that within the local budget, there are no financial resources available to regenerate the ruined sites of the town. Paradoxically, considering the financial resources provided by the EU funding programs, they are less used in second-tier towns (personal conversation with a project manager in the ADETIM Directorate of Timiş County, Romania). In such instances, urban regeneration of local derelict places was ignored and abandoned by local authorities. Old monumental industrial buildings remain derelict and abandoned, illustrating the indifference of their owners, as well as the local government's neglect. Many ruined sites under national and local administration remained derelict, unveiling apathy, and illusory regeneration programs [62,123].

Summing it all up, in spite of a national legal framework supporting regeneration of derelict places and local regulation for urban ruined sites restoration, the abandoned places of Lugoj municipality remain neglected. Although local authorities may intend to intervene, the tensions and the conflicting perspectives between national and local legislative backgrounds discourage local initiatives. However, as was mentioned, some actions have been initiated but the very slow pace means that the sites continue to remain derelict. When the ruined sites are held as private property, there has been advocacy to bring in multiple investors since financial resources remain the main constraint in the redevelopment of these sites. Even though there are multiple opportunities to use EU funds for the local urban regeneration, they remain under-accessed, thus, limiting further urban regeneration actions. Furthermore, a more collaborative manner approaching these questions could enhance both the visions and practices in the redevelopment of urban derelict places. These abandoned places could be seen as sites with multiple opportunities for further development, turning them into functional sites (new productive units, places as touristic resources in the case of the old factories, new services, or after decontamination, residential areas considering the decline of the former military sites, urban parks in the case of the ruined rail transport areas, etc.). A new vision for these derelict places could be reinforced to design, three decades after the state-socialist collapse, a new common policy agenda on the local urban dereliction. Such a document would bring together all different stakeholders for local urban regeneration (from the local authorities, policy makers, private investors, representatives of the local residents etc.), focusing their efforts on the local abandoned places and urban marginalized sites' restoration.

\section{Conclusions}

Considering different impacts of postsocialist changes in Romania [132], the paper discussed the issue of Romanian postsocialist urban dereliction, with a nonmetropolitan area as a case study, explaining how the city's government mismanagement on postsocialist economic transition led to the cities' derelict places. The research portrayed the perspectives of the municipality, presumably driven by growth discourses, of the local residents and of the ex-workers, accusing them of faulty privatization and urban mismanagement in local regeneration. Such an approach pinpoints tension 
and the conflicting interests of involved actors, in the local ruins production [18]. The article has shown that, similarly to other European urban settlements, the (re)reproduction of urban dereliction, as a consequence of the new postsocialist economic rules in urban restructuring, is a common feature in the process of the Romanian postsocialist urban identity formation. They occurred in the post-90 economic decline and urban restructuring, governed by the global capitalism [12,18], and wrong privatization, illustrating the illusions of the progress [6] in the local urban planning. Although in other Eastern European Countries, some derelict and ruined sites were restored [7,44], in Romanian cities and towns, the ruins still stand as proofs of the transition to a market economy. Against such a background, the national context of de-/reindustrialization, demilitarization, and postsocialist shifts in urban restructuring, framed by mismanagement in urban and economic restructuring and in postsocialist urban regeneration, is the main contributor to the present urban dereliction. Whether they are industrial, residential, rail, or military ruined sites, they are consequences of deliberate interventions managed by different local, regional, or national actors, stakeholders and policies, with speculative actions in the context of urban restructuring. In addition, urban mismanagement accompanied by ignorance of local communities led to the urban dereliction with urban ruins remaining spaces of indifference [18]. For that reason, this topic remains a "slippery subject" [6] (p. 467), grounded in the scene of post-90 politics and economic transformations.

Urban derelict places, 30 years after the state-socialism collapse, are ubiquitous scenes in the Romanian cities and towns, illustrating ignorance, failure, and abandonment. Many urban ruins appeared due to the post-socialist industrial decline, framed by the new market economy. Against such a background, both the former state-socialist plants and the traditional factories with importance for the national culture, failed. The national and local industrial decline turned into derelict places, swirling other related places and damaging the inner patterns of the cities. Rail transport areas were the first, because of their close relationship with the former state-socialist industries. Places of residential districts turned to ruins because of their state-socialist design, only to reproduce the working class [93]. During postsocialism the people living in these districts became the owners of the flats and were associated with the home improvement actions, the old state-socialist infrastructure became redundant and turned to ruins. Demilitarization of Romanian urban areas was another driving force in the urban dereliction appearance. The case developed in this narrative is applicable to Romanian nonmetropolitan areas and to the municipality of Lugoj. The local industrial restructuring generated many derelict places, with important traditional plants for the national culture that was turned to ruins [123].

The findings of the study illustrate conflicting postures between the voice of the local community and the local government arguments. On one hand, there are voices blaming the local government's indifference, at periods when the town needs important interventions in local regeneration. On the other hand, local government shifts the responsibility to the new owners of the current derelict sites, and for those ruined places under the state's ownership, motivating the absence of the financial resources. However, this argument contrasts with the postsocialist opportunity in using the EU funding programs in local urban development. Such projects could regenerate the ruined sites, especially those with cultural significance for the local and national culture. Meanwhile, totally blaming one another, the local community remains the main victim. Besides theoretical projects, strategies and large aspirations of the local government in urban regeneration, [133], many important sites remain abandoned with their ruins harming the local community. Furthermore, the tensions between the local decentralized ambitions on urban development and the centralized management on urban postsocialist planning, maintain local urban dereliction. Therefore, the Romanian urban decentralization in local policies is rather theoretic with no positive feedbacks. 
Thirty years since the Romanian state-socialism collapse, it is a time of reflection on what needs to be done to adjust the Romanian urban communities to the European urban welfare. Consequently, this study calls for both urban regeneration (because ruins could still be restored, serving the local community and its culture), and for further fertile research in the field. Such derelict places and their related decayed neighborhoods are common features in the locally ruined sites. Such groups and species pushed toward such marginal spaces generate usage and activities that deserve to be further studied in their own rights. Assessing local urban dereliction, and an in-depth analysis of its damages in the local community connected to the above mentioned issues, studying the risk potential of urban ruins [123], and applying for EU funds in local urban development, are actions in the local urban regeneration that have to be immediately kick-started, for timely recuperation of urban dereliction. Apportioning blame on the former state-socialism with artificial industrialization, and the current postsocialism governed by speculations, corruption, wrong interventions, and policies [18] without sustainable visions is not enough. Now it is time for sustainable action for the cities' benefit, for their culture and to their postsocialist identity formation [134]. The past could be blamed, but not destroyed. Does the past have any future in the further postsocialist urban identity formation? If yes, it is time to act before destroying the local urban identities. In other words, 30 years after the state-socialism collapse is a worthy time for good reflections and critical research on further urban regeneration strategies, in order to solve the current urban dereliction. In doing so, as Jayne (2012) [4] argued, the local government and the current public-private actors in urban development, have to (re)design more progressive alternatives and politics on the local agendas, regarding the capitalization of the local urban ruins. After two decades of postsocialist urban change, the urban ruins unveil the ignorance of national and local governments and communities, being places of failure and abandonment.

Finally, the article highlighted that urban ruins are still a common feature in Romania. Urban dereliction and their related ruins in urban space are results of the present capitalist expansion, relating to uneven geography of capitalist development [135]. Although ruins are "never static objects" [58] (p. 3) this contribution showed that Romanian postsocialist urban dereliction and the local urban ruins are-three decades after the state-socialism collapse-quiescent spaces both in the face of the post-1990s capitalist development, and of the local municipal ignorance of the contemporary Europeanization trends on urban sustainability, from which we all have to learn.

Author Contributions: The authors of this article have equal contribution. Conceptualization I.S.J. and S.V.; methodology I.S.J. and S.V.; investigation I.S.J. and S.V.; data creation I.S.J.; writing original draft preparation I.S.J. and S.V.; writing review and editing S.V. and I.S.J.; visualization and supervision S.V.; funding acquisition I.S.J. Both authors have read and agreed to the published version of the manuscript. Parts of the findings and results of this study have been presented by the authors at the 6th International Urban Geographies of Post-Communist States Conference 25 Years of Urban Change, CATference 23-26 September 2015, Prague, Czech Republic. Title of the presentation: Living in/with dereliction: The case of small and medium sized towns in Timis County, Romania. All authors have read and agreed to the published version of the manuscript.

Funding: This research received no external funding. The APC fee for this article is funded by the Project CNFIS-FDI-2020-0253, West University of Timisoara.

Acknowledgments: The authors would like to extend their thanks to: West University of Timisoara, DCSCU, Romania for the APC fee support; the anonymous reviewers for their comments on the earlier manuscript and to Margareta Lelea, for the last proofreading of this article.

Conflicts of Interest: The authors have no conflict of interest to disclose.

\section{References}

1. Mah, A. Memory, uncertainty and industrial ruination: Walker riverside, Newcastle upon Tyne. Int. J. Urban Reg. Res. 2010, 34, 398-413. [CrossRef]

2. Mah, A. Industrial Ruination, Community and Place Landscapes and Legacies of Urban Decline; University of Toronto Press: Toronto, ON, Canada, 2012.

3. Turok, I. Redundant and marginalized spaces. In Cities and Economic Change; Paddison, R., Hutton, T., Eds.; Sage: London, UK, 2015; pp. 74-93. 
4. Jayne, M. Mayors and urban governance: Discursive power, identity and local politics. Soc. Cult. Geogr. 2012, 13, 29-37. [CrossRef]

5. Weck, S.; Lobato, I.R. Social exclusion: Continuities and discontinuities in explaining local patterns. Local Econ. 2015, 30, 765-782. [CrossRef]

6. DeSilvey, C.; Edensor, T. Reckoning with ruins. Prog. Hum. Geogr. 2013, 37, 465-485. [CrossRef]

7. Stanilov, K. (Ed.) The Post-Socialist City: Urban Form and Space Transformations in Central and Eastern Europe after Socialism; Springer: Dordrecht, The Netherlands, 2007.

8. Edensor, T. Industrial Ruins. Space, Aesthetics and Materiality; Berg: Oxford, UK, 2005.

9. Edensor, T. The ghosts of industrial ruins: Ordering and disordering memory in excessive space. Environ. Plan. D Soc. Space 2005, 23, 829-849. [CrossRef]

10. Loures, L.; Panagopoulos, T. From derelict industrial areas towards multifunctional landscapes and urban renaissance. WSEAS Trans. Environ. Dev. 2007, 3, 181-188.

11. Loures, L.; Panagopoulos, T. Sustainable Reclamation of Industrial Areas in Urban Landscapes; Wit Press: Southampton, UK, 2007.

12. Martin, D. Introduction: Towards a political understanding of new ruins. Int. J. Urban Reg. Res. 2014, 38, 1037-1046. [CrossRef]

13. Martin, D. Translating space: The politics of ruins, the remote and peripheral places. Int. J. Urban Reg. Res. 2014, 38, 1102-1119. [CrossRef]

14. Strangleman, T.; Mah, A. Industrial Ruination, Community, and Place: Landscapes and Legacies of Urban Decline; University of Toronto Press: Toronto, ON, Canada, 2014; Volume 38, pp. 1126-1127. [CrossRef]

15. Franck, K.A.; Stevens, Q. Tying down loose space. In Loose Space: Possibility and Diversity in Urban Life; Routledge: London, UK, 2007; pp. 1-34.

16. González-Ruibal, A. Time to destroy: An archaeology of supermodernity. Curr. Anthropol. 2008, 49, $247-279$. [CrossRef]

17. Hirt, S.A.; Stanilov, K. Twenty Years of Transition: The Evolution of Urban Planning in Eastern Europe and the Former Soviet Union, 1989-2009; UN-HABITAT: Nairobi, Kenya, 2009.

18. Kideckel, D. Getting by Post-Socialist Romania: Labor, the Body and Working-Class Culture; Indiana University Press: Bloomington, IN, USA, 2008.

19. Kovácz, Z.; Weissner, R.; Zischner, R. Urban renewal in the inner city of Budapest: Gentrification from a postsocialist perspective. Urban Stud. 2013, 50, 22-38. [CrossRef]

20. Puşcă, A. Industrial and human ruins of postcommunist Europe. Space Cult. 2010, 13, 239-255. [CrossRef]

21. Smith, A.; Timár, J. Uneven transformations: Space, economy and society 20 years after the collapse of state-socialism. Eur. Urban Reg. Stud. 2010, 17, 15-25. [CrossRef]

22. Sýkora, L. New socio-spatial formations: Places of residential segregation and separation, Czechia. Tijdschr. Econ. Soc. Geogr. 2009, 100, 417-435. [CrossRef]

23. Sýkora, L. Post-socialist cities. In International Encyclopedia of Human Geography; Kitchin, R., Thrift, N., Eds.; Elsevier: Oxford, UK, 2009; pp. 387-395.

24. Stanilov, K.; Sýkora, L. Planning markets and patterns of residential growth in post-socialist metropolitan Prague. J. Archit. Plan. Res. 2012, 29, 278-291. [CrossRef]

25. Young, C.; Kaczmarek, S. The socialist past and postsocialist urban identity in Central and Eastern Europe: The case of Łódź, Poland. Eur. Urban Reg. Stud. 2008, 15, 53-70. [CrossRef]

26. Nefs, M. Unused urban space: Conservation or transformation? Polemics about the future of urban wastelands and abandoned buildings. City Time 2006, 2, 47-58.

27. Teixeira, A.C.; Barros, M.J. Local municipalities' involvement in promoting the internationalisation of SMEs. Local Econ. 2014, 29, 141-162. [CrossRef]

28. Bradshaw, M.J.; Stenning, A.C. (Eds.) East Central Europe and the Former Soviet Union: The Post Socialist Economies; Pearson: Harlow, UK, 2004.

29. Dunford, M.; Smith, A. Catching up or falling behind? Economic performance and regional trajectories in the 'New Europe'. Econ. Geogr. 2000, 76, 169-195. [CrossRef]

30. Light, D.; Young, C. Reconfiguring socialist urban landscapes: The'left-over' of state-socialism in Bucharest. Hum. Geogr. J. Stud. Res. Hum. Geogr. 2010, 4, 5-16.

31. Marcińczak, S.; Sagan, I. The socio-spatial restructuring of Łódź, Poland. Urban Stud. 2011, 48, 1789-1809. [CrossRef] 
32. Marcińczak, S. The evolution of spatial patterns of residential segregation in Central European Cities: The Łódź functional urban region from mature socialism to mature post-socialism. Cities 2012, 29, 300-309. [CrossRef]

33. Marcińczak, S.; Musterd, S.; Stepniak, M. Where the grass is greener: Social segregation in three major Polish cities at the beginning of the 21st Century. Eur. Urban Reg. Stud. 2012, 19, 383-403. [CrossRef]

34. Marcińczak, S.; Gentile, M.; Rufat, S.; Chelcea, L. Urban geographies of hesitant transition: Tracing socioeconomic segregation in Post-Ceausescu Bucharest. Int. J. Urban Reg. Res. 2014, 38, 1399-1417. [CrossRef]

35. Nădejde, Ş.; Pantea, D.; Dumitrache, A.; Braulete, I. Romania: Consequences of small steps policy. In Rise and Decline of Industry in Central and Eastern Europe. A Comparative Study of Cities and Regions in Eleven Countries; Muller, B., Finka, M., Lintz, G., Eds.; Springer: Dordrecht, The Netherlands, 2005; pp. 179-194.

36. Pickles, J. The spirit of post-socialism: Common spaces and the production of diversity. Eur. Urban Reg. Stud. 2010, 17, 127-140. [CrossRef]

37. Stenning, A. Placing (post-) socialism. The making and remaking of Nowa Huta, Poland. Eur. Urban Reg. Stud. 2000, 7, 99-118. [CrossRef]

38. Stenning, A.; Smith, A.; Rochovská, A.; Swiatek, D. Domesticating Neoliberalism: Spaces of Economic Practice and Social Reproduction in Post-Socialist Cities; Wiley-Blackwell: Oxford, UK, 2010.

39. Chelcea, L. Bucureştiul Postindustrial, Memorie, Dezindustrializare şi Regenerare Urbană; Polirom: Bucharest, Romania, 2008.

40. Iancu, S. Ruine Industriale ale Epocii de Aur (industrial ruins of the golden age). România Liberă. 28 May 2007. Available online: http://www.romanialibera.ro/actualitate/fapt-divers/ruine-industriale-epocii-de-aur-96496 (accessed on 12 July 2018).

41. Ivanov, C. Cum pot fi Transformate Ruinele Industriale în Minuni Arhitecturale (How Industrial Ruins Could Turn to Architecture Wonderlands). 29 November 2010. HotNews.ro. Available online: http://economie. hotnews.ro/stiri-imobiliar-8079922-cum-pot-transformate-ruinele-industriale-bijuterii-arhitectonice.htm (accessed on 12 July 2018).

42. Kiss, E. Restructuring in the industrial areas of Budapest in the period of transition. Urban Stud. 2002, 39, 33-56. [CrossRef]

43. Kiss, E. Spatial impacts of post-socialist industrial transformation in the major Hungarian cities. Eur. Urban Reg. Stud. 2004, 11, 81-87. [CrossRef]

44. Kiss, E. The evolution of industrial areas in Budapest after 1989. In The Post-Socialist City: Urban Form and Space Transformations in Central and Eastern Europe after Socialism; Stanilov, K., Ed.; Springer: Dordrecht, The Netherlands, 2007; pp. 147-172.

45. Lefebvre, H. The state and society. In State, Space, World: Selected Essays by Henri Lefebvre; Brenner, N., Elden, S., Eds.; University of Minnesota Press: Minneapolis, MN, USA, 2009; pp. 51-68.

46. Chelcea, L. The 'Housing Question' and the state-socialist answer: City, class and state remaking in 1950s Bucharest. Int. J. Urban Reg. Res. 2012, 36, 281-296. [CrossRef]

47. Lewandowski, J.D. Rescuing critique: On the ghetto photography of Camilo Vergara. Theory. Cult. Soc. 2008, 25, 285-308. [CrossRef]

48. Mickiewicz, T.; Zalewska, A. Deindustrialization. Lessons from the Structural Outcomes of Post-Communist Transition; Working Paper 463; William Davidson Institute: Ann Arbor, MI, USA, 2002.

49. Muir, J. Neoliberalising a divided society? The regeneration of Crumlin Road Gaoland and Girdwood Park, North Belfast. Local Econ. 2014, 29, 52-64. [CrossRef]

50. Ross, B.; Mitchell, D. Neoliberal landscapes of deception: Detroit, Ford Field and the Ford Motor Company. Urban Geogr. 2004, 25, 685-690. [CrossRef]

51. Golubchikov, O.; Badyina, A.; Makhrova, A. The hybrid spatialities of transition: Capitalism, legacy and uneven urban economic restructuring. Urban Stud. 2013, 51, 617-633. [CrossRef]

52. Ren, X. The political economy of urban ruins: Redeveloping Shanghai. Int. J. Urban Reg. Res. 2014, 38, 1081-1091. [CrossRef]

53. Beesley, C. Globalization and corruption in post-Soviet countries: Perverse effects of economic openness. Eurasian Geogr. Econ. 2015, 56, 170-192. [CrossRef]

54. Mitchell, D. Cultural Geography: A Critical Introduction; Blackwell: Oxford, UK, 2000. 
55. NIS. National Institute of Statistics of Romania, Bucharest. 2015. Online Database TempoOnline. Available online: www.tempoonline.ro (accessed on 15 July 2018).

56. Jucu, I.S. Romanian post-socialist industrial restructuring at the local scale: Evidence of simultaneous processes of de-/reindustrialization in the lugoj municipality of Romania. J. Balk. Near East. Stud. 2015, 17, 408-426. [CrossRef]

57. Jucu, I.S. Lugoj the municipality of seven women to a man. From myth to post socialist reality. An. Univ. Vest Timis. Ser. Geogr. 2009, 19, 133-146.

58. Schönle, A. Ruins and history: Observations on Russian approaches to destruction and decay. Slav. Rev. 2006, 65, 649-669. [CrossRef]

59. Stoler, A.L. Imperial debris: Reflections on ruins and ruination. Cult. Anthropol. 2008, 23, 191-219. [CrossRef]

60. Calixto, M.; Brito, M. Aparecida de. os Vazios Urbanos e o Processo de Redefinição Socioespacial em Dourados. (Assessing Urban Processes of Spatial Redefining); MS. UFMS: Campo Grande, Brazil, 2004.

61. Millington, N. Post-industrial imaginaries: Nature, representation and ruin in Detroit, Michigan. Int. J. Urban Reg. Res. 2013, 37, 279-296. [CrossRef]

62. Voiculescu, S.; Jucu, I.S. Producing urban industrial derelict places: The Case of the Solventul petrochemical plant in Timişoara. Eur. Urban Reg. Stud. 2016, 23, 765-781. [CrossRef]

63. Somers-Hall, H. The concept of ruin: Sartre and the existential city. Urbis Res. Forum 2009, 1, 17-19.

64. Theodore, N.; Peck, J. Framing neoliberal urbanism: Translating 'Commonsense' urban policy across the OECD Zone. Eur. Urban Reg. Stud. 2011, 19, 20-41. [CrossRef]

65. Brenner, N.; Theodore, N. Neoliberalism and the Urban Condition. City 2005, 9, 101-107. [CrossRef]

66. Schumpeter, J. Capitalism, Socialism and Democracy; Routledge: New York, NY, USA, 1994.

67. Zanocea, C. Singur pe Ruinele Industriei Comuniste. (Alone on the Communist Ruins). 4 February 2014. Ziarul de Roman. Available online: http://www.ziarulderoman.ro/singur-pe-ruinele-industriei-comuniste/ (accessed on 20 July 2018).

68. Boym, S. Ruins of the avant-garde: From Tatlin's tower to paper architecture. In Ruins of Modernity; Hell, J., Schönle, A., Eds.; Duke University Press: Durham, NC, USA, 2010; pp. 58-88.

69. Tonnelat, S. 'Out of frame': The (in) visible life of urban interstice. Ethnography 2008, 9, 291-324. [CrossRef]

70. Armstrong, J. Everyday afterlife: Walter Benjamin and the politics of abandonment in Saskatchewan, Canada. Cult. Stud. 2011, 25, 273-293. [CrossRef]

71. Doron, G. The dead zone and the architecture of transgression city: Analysis of urban trends. City 2000, 4, 247-263. [CrossRef]

72. Jones, H. Exploring the creative possibilities of awkward space in the city. J. Landsc. Urban Plan. 2007, 83, 70-76. [CrossRef]

73. Jorgensen, A.; Tylecote, M. Ambivalent landscapes-wilderness in the urban interstices. Landsc. Res. 2007, 32, 443-462. [CrossRef]

74. Berger, A. Drosscape: Wasting Land in Urban America; Architectural Press: Princeton, NJ, USA, 2007.

75. Bagaeen, S. Redeveloping former military sites: Competitiveness, urban sustainability and public participation. Cities 2006, 23, 339-352. [CrossRef]

76. Barndt, K. Memory Traces of an Abandoned set of Futures Dustrial Ruins in the Post-Industrial landscapes of East and West Germany. In Ruins of Modernity; Hell, J., Schönle, A., Eds.; Duke University Press: Durham, NC, USA, 2007; pp. 270-293.

77. Hell, J.; Schönle, A. (Eds.) Ruins of Modernity; Duke University Press: Durham, NC, USA, 2010.

78. Lahusen, T. Decay or endurance? The ruins of socialism. Slav. Rev. 2006, 65, 736-746. [CrossRef]

79. Cristiaanse, K. The City as a Loft; Berlin: Top 38; ETH Zurich: Berlin, Germany.

80. Loures, L.; Horta, D.; Panagopoulos, T. Strategies to reclaim derelict industrial areas. WSEAS Environ. Dev. 2006, 5, 599-604.

81. Unt, A.L.; Travlou, P.; Bell, S. Blank space: Exploring the sublime qualities of urban wilderness at the former fishing harbor in Tallinn, Estonia. Landsc. Res. 2014, 39, 267-286. [CrossRef]

82. Davis, S. Military landscapes and secret science: The case of Orford Ness. Cult. Geogr. 2008, 15, 143-149. [CrossRef]

83. Farley, P.; Roberts, M.S. Edgelands: Journeys into England's True Wilderness; Jonathan Cape: London, UK, 2011.

84. Rosa, B. Infrastructure and indeterminacy: The production of residual space. In Proceedings of the CRESC Conference 'Framing the City', Manchester, UK, 6-9 September 2011. 
85. Qviström, M. Network ruins and green structure development: An attempt to trace relational spaces of a railway ruin. Landsc. Res. 2012, 37, 257-275. [CrossRef]

86. Nadolu, B.; Lucheş, D.; Dincă, M. The patterns of depopulation in Timişoara-Research note. Sociol. Românescă SR 2011, 9, 76-89.

87. Nadolu, B.; Dincă, M.; Lucheş, D. Urban Shrinkage in Timişoara, Romania; Research Report; West University of Timişoara: Timisoara, Romania, 2010.

88. Krieger, M.H. Media tools for urban design. In Companion to Urban Design; Banerjee, T., Loukaitou-Sideris, A., Eds.; Routledge: London, UK, 2011; pp. 238-248.

89. Rossiter, W.; Price, L. Local economic strategy development under Regional Development Agencies and Local Enterprise Partnership. Applying the lens of the multiple streams framework. Local Econ. 2013, 28, 852-862. [CrossRef]

90. Bernstein, S. Rising from the Ruins. The Aestheticization of Detroit's Industrial Landscape; Lewis and Clark College: Portland, OR, USA, 2013.

91. Andreşoiu, B.; Bonciocat, Ş.; Ioan, A.; Oţoiu, N.A.; Chelcea, L.; Simion, G. Kombinat. Ruine Industriale ale Epocii de Aur; Igloo Patrimoniu: Bucharest, Romania, 2007.

92. Jordan, P. Regional identities and regionalization in East Central Europe. Post Sov. Geogr. Econ. 2001, 42, 235-265. [CrossRef]

93. Petrovici, N. Workers and the city: Rethinking the geographies of power in post-socialist urbanization. Urban Stud. 2012, 49, 2377-2397. [CrossRef]

94. Vesalon, L.; Cretan, R. "Little Vienna" or "European avant-garde city"? Branding narratives in a Romanian City. J. Urban Reg. Anal. 2019, 11, 17-34.

95. Cojocar, A.; Industria Trece Printr-un val de Inchideri care Afecteaza Cresterea Economica. Care sunt Cauzele Dezindustrializarii de dupa 89 si unde s-a gresit? Am Privatizat Destul sau Prea Putin? De ce nu am Atras Destui noi Investitori? Ziarul Financiar. 7 March 2013. Available online: https://www.zf.ro/analiza/industria-trece-printr-val-inchideri-afecteaza-cresterea-economica-cauzeledezindustrializarii-dupa-89-unde-s-gresit-privatizat-destul-prea-putin-atras-destui-investitori-10648895 (accessed on 10 August 2018).

96. Creţan, R.; O'Brien, T. Corruption and conflagration: (in) justice and protest in Bucharest after the Colectiv fire. Urban Geogr. 2020, 41, 368-388. [CrossRef]

97. Preda, C.C. Ministerul Economiei Caută Potenţialul Nevalorificat Printre Ruinele Industriei, Ziarul Hunedoreanului. 2013. Available online: http://zhd.ro/ministerul-economiei-cauta-potentialul-nevalorificatprintre-ruinele-industriei (accessed on 6 June 2018).

98. DIGI 24. Business Club. Industria Sticlei în România în ruine. Ultima Suflare a Sticlei de Pădurea Neagră. 2014. Available online: http://www.digi24.ro/Stiri/Digi24/Economie/Stiri/BUSINESS+CLUB+Industria+ sticlei+din+Romania+in+ruine+Ultima+suflonline (accessed on 10 June 2016).

99. Deșteptarea. Prin Ruinele Industriei Băcăuane. 2013. Available online: athttp://www.desteptarea.ro/prinruinele-industriei-bacauane/ (accessed on 10 June 2016).

100. Kotz, D.M. Globalization and neoliberalism. Rethink. Marx. 2002, 14, 64-79. [CrossRef]

101. Soederberg, S. The Politics of New Financial Architecture: Re-Imposing Neoliberal Domination in the Global South; Zed Books: New York, NY, USA, 2004.

102. Orenstein, M.A. What happened in East European (political) economies?: A balance sheet for neoliberal reform. East Eur. Politics Soc. 2009, 23, 479-490. [CrossRef]

103. Pickles, J.; Smith, A. (Eds.) Theorising Transition: The Political Economy of Postcommunist Transformation; Routledge: London, UK, 1998.

104. Avram, C. În Premieră (In First Run). 2014. Available online: http://www.antena3.ro/romania/ romania-otravita-ruinele-industriei-comuniste-ne-baga-in-pamant-cu-trei-ani-mai-devreme-230163.html (accessed on 10 June 2016).

105. Dochia, A. Despre Soarta Tristă a Industriei Chimice Româneşti. Ziarul Financiar. 2012. Available online: http://www.zf.ro/opinii/despre-soarta-trista-a-industriei-chimice-romanesti (accessed on 21 October 2018).

106. Ianoş, I. Dinamică Urbană; Tehnică: Bucharest, Romania, 2004.

107. Ianoş, I.; Heller, W. Spaţiu, Economie şi Sisteme de Aşezări; Tehnică: Bucharest, Romania, 2006. 
108. Jigoria, L.; Popa, N. Industrial brownfields: An unsolved problem in post-socialist cities. A comparison between two mono-industrial cities: Resita (Romania) and Pancevo (Serbia). Urban Stud. 2016, 54, 2719-2738. [CrossRef]

109. Dima, A. România te Iubesc. Available online: http://romaniateiubesc.stirileprotv.ro/stiri/romania-te-iubesc/ romania-te-iubesc-industria-romaneasca-marire-si-decadere.html (accessed on 10 June 2015).

110. Savu, C. Cine a pus ARO pe butuci. In România te Iubesc; Herlo, P., Năstase, R., Dima, A., Savu, C., Angelescu, P., Eds.; Humanitas: Bucharest, Romania, 2018; pp. 210-229.

111. Domanski, B. Industrial change and foreign direct investments in the post socialist economy: The case of Poland. Eur. Urban Reg. Stud. 2003, 10, 99-118. [CrossRef]

112. Gafiuc, J. Platforma Iadului. Rulmentul Brasov pe Vremuri Mandria Socialismului a Devenit o ruină. 23. Libertatea, Iunie. 2019. Available online: https://www.libertatea.ro/stiri/platforma-iadului-cum-arata-azirulmentul-brasov-mandria-socialismului-romanesc-2673705 (accessed on 12 August 2019).

113. Chowdhury, S.; Kain, J.H.; Adelfio, M.; Volkhko, Y.; Norrman, J. Greening the brown. A bio-based land-use framework for analyzing the potential of urban brownfields in an urban circular economy. Sustainability 2020, 12, 6278. [CrossRef]

114. Gamju, M. Magneții s-au Întors pe Ruinele Fostelor Platforme Industrial. Actualitate. Mesagerul hunedorean, Hunedoara. 2013. Available online: https://www.mesagerulhunedorean.ro/magnetii-s-au-intors-pe-ruinelefostelor-platforme-industriale (accessed on 12 August 2019).

115. National Institute of Statistics Romania (NIS). Breviar Statistic al Municipiului Lugoj, 2009-2010; NIS: Timisoara, Romania, 2010.

116. Jucu, I.S. Analiza Procesului de Restructurare Urbană în Municipiul Lugoj; Universităţii de Vest: Timisoara, Romania, 2011.

117. Wẹclawowicz, G. From egalitarian cities in theory to non-egalitarian cities in practice: The changing social and spatial patterns in Polish cities. In Of States and Cities: The Partitioning of Urban Space; Marcuse, P., van Kempen, R., Eds.; Oxford University Press: Oxford, UK, 2002; pp. 183-199.

118. Egresi, I. Foreign direct investment in a recent entrant to the EU. The case of the automotive industry in Romania. Eurasian Geogr. Econ. 2007, 45, 134-156. [CrossRef]

119. Mariş, C. Unde e textila de altă dată? Actualitatea 2010, 708, 8-9.

120. Toma, D. În prag de sărbători locuitorii din Mondial se luptă cu frigul şi foamea (In winter the inhabitants of Mondial face with cold and hungry). Actualitatea 2013, 1176, 8.

121. Niţoiu, C. Fabrica de lapte din Lugoj cumpărată de fiica fostului director CFR Timişoara. Redeşteptarea 2007, 1180, 6 .

122. Gaidoş, C.O. Complexul industrial Abatorul şi Fabrica de gheaţă 1911-1912. Monitorul de Lugoj 2005, 77, 8.

123. Jucu, I.S.; Pavel, S. Post-communist urban ecologies of Romanian medium-sized towns. Forum Geogr. 2019, 18, 170-185.

124. Dawidson, K.E. Redistribution of land in post-communist Romania. Eurasian Geogr. Econ. 2005, 46, 618-632. [CrossRef]

125. Adiv, N. Beating the Bounds: A Walking Exploration of the Capital Corridor Rail Line. 2011. Available online: http://beatingthebounds.typepad.com (accessed on 15 March 2018).

126. Hananel, R. Can centralization, decentralization and welfare go together?: The case of Massachusetts affordable housing policy (Ch. 40B). Urban Stud. 2014, 51, 2487-2502. [CrossRef]

127. Opris, P. Rachete Balistice Sovietice in Romania (1961-1998). 2018. Available online: https://www.contributors. ro/rachete-balistice-sovietice-in-romania-1961-1998-2/ (accessed on 25 July 2019).

128. Lugoj Tion. La Lugoj se Inființează un nou Cartier Militari. 22 June 2011. Available online: https: //www.tion.ro/lugoj/la-lugoj-se-infiinteaza-un-nou-cartier-militari-342246/ (accessed on 12 July 2016).

129. Obeadă, C. Cele mai Multe clădiri Emblem ale Lugojului Sunt în Ruină de ani de zile. Redesteptarea. 18 June 2013. Available online: https://redesteptarea.ro/galerie-foto-cele-mai-multe-cldiri-emblem-alelugojului-sunt-in-ruin-de-ani-de-zile/ (accessed on 12 July 2016).

130. Creţan, R. Mapping protests against dog culling in post-communist Romania. Area 2015, 47, $155-165$. [CrossRef]

131. Gandi, M. Urban nature and ecological imaginary. In The Routledge Companion to Urban Imaginaries; Lindner, C., Meissner, M., Eds.; Routledge: London, UK, 2018; pp. 54-63. 
132. Matichescu, M.L.; Drăgan, A.; Lucheș, D. Channels to West: Exploring the Migration Routes between Romania and France. Sustainability 2017, 9, 1861.

133. City Hall of the Municipality of Lugoj. The Strategy of Urban Development of the Municipality of Lugoj; Nagard: Lugoj, Romania, 2012.

134. Ilovan, O.R.; Jordan, P.; Havady-Nagy, K.X.; Zametter, T. Identity matters for development. Austrian and Romanian experiences. Transylvanian Rev. 2016, 25, 261-276.

135. Harvey, D. Spaces of Neoliberalization: Towards a Theory of Uneven Geographical Development; Franz Steiner Verlag: Munich, Germany, 2005.

(C) 2020 by the authors. Licensee MDPI, Basel, Switzerland. This article is an open access article distributed under the terms and conditions of the Creative Commons Attribution (CC BY) license (http://creativecommons.org/licenses/by/4.0/). 